\title{
Analisis Efektifitas Halte Di Kota Medan
}

\author{
Oloan SITOHANG ${ }^{1 *} \cdot$ Anto Ervin SITUMORANG ${ }^{2}$ \\ ${ }^{1}$ Staf Pengajar Teknik Sipil Universitas Katolik Santo Thomas \\ ${ }^{2}$ Program Studi Teknik Sipil Universitas Katolik Santo Thomas
}

\begin{abstract}
In the city of Medan, bus shelter where passengers could wait for Angkot (local paratransit) to stop has not been fully utilized. In this study, we evaluate the effectiveness of bus shelters along main corridor in Medan. The evaluation is conducted based on official government standard, occupancy level, and also user perception. We have surveyed 35 shelters, among which 16 stops (45.71\%) are mid-block, 8 stops (22.86\%) are farside, and 11 types (31.43\%) are near-side. In accordance with bus stop standards, only 9 stops $(25.71 \%)$ are considered. The results of this study indicate that the factors that influence the use of shelters in waiting for Angkot are as follows: awareness about shelters location, distance to reach shelters, waiting times at shelters, shelter facilities. The effectiveness of using bus stops in Medan City is 32.58\%, which means the shelter in this corridor is considered very ineffective (between 20.10\%-40.00\%).
\end{abstract}

Kata kunci: halte, efektivitas, responden, pengguna

\section{Pendahuluan}

\section{Latar Belakang}

Indra Syahputra, mengamati keberadaan halte di Kota Medan seharusnya dapat mendisiplinkan angkutan umum untuk dapat menaikkan/menurunkan penumpang di halte. Nyatanya masih banyak angkutan umum yang menaikkan/menurunkan penumpang di sembarang tempat. Halte yang dibangun seharusnya dapat digunakan sebagaimana mestinya, sehingga angkutan umum seperti Trans Mebidang dan Angkutan Umum (Angkot) berhenti seenaknya, sehingga menjadi salah satu faktor penyebab kemacetan. Hal ini terlihat di saat jam-jam sibuk, seperti pagi hari, siang dan sore hari, ketika jam pergi, istirahat dan pulang kerja atau sekolah.

Menurut Waspada.co.id, tidak difungsikannya halte di Kota Medan membuat tempat menunggu angkutan kota (angkot) sering dimanfaatkan oleh sejumlah warga untuk membuka usaha. Salah satunya, halte di Jalan SM. Raja, tepatnya di samping Jalan Air Bersih, Kecamatan Medan Kota. Menurut Media Indonesia, dengan topik "Secuil Peradaban Dari Halte", menemukan kenyamanan di halte Kota Medan bukan perkara mudah. Sama tidak mudahnya menciptakan dan memelihara halte menjadi tempat umum yang indah dan menyenangkan. Di kota ini, halte hampir berubah fungsinya dari sekadar tempat pemberhentian bus ataupun angkutan umum di dalam kota. Pantauan Media Indonesia, ada halte di lokasi Jalan Pusat Pasar di Medan kondisinya memprihatinkan. Tidak digunakan untuk tempat pemberhentian angkutan umum, malah digunakan sejumlah pedagang untuk menumpuk sayur dan buah dagangan mereka. Sebagai tempat turun dan naiknya penumpang angkutan umum, halte terkadang diperhatikan, namun tak jarang diterlantarkan. Fasilitas di

*penulis korespondensi

e-mail: obed_sito@yahoo.com 
halte yang disediakan pun seadanya. Ada kesan, sebagai fasilitas umum (fasum), sama halnya dengan halte di Jalan Putri Hijau. Halte tersebut digunakan sebagai tempat berjualan rokok, pulsa, dan jualan makanan. Akibatnya calon penumpang angkutan umum enggan menunggu angkutan umum di halte yang sudah disediakan. Hal ini menimbulkan rasa tidak aman dan nyaman serta mempersempit ruang gerak pengguna halte. Halte di Jalan Dr. Mansyur, dekat Kampus USU, lebih parah lagi. Lantainya rusak berat, keramiknya hancur. Tak satupun orang ingin berada di situ. Jadilah halte ini menjadi sia-sia dibangun.

Penelitian yang dilakukan Departemen Teknik Sipil, Fakultas Teknik, Universitas Sumatra Utara (FT USU) tahun lalu, menyimpulkan bahwa permasalahan halte di Kota Medan ini sangat beragam. Hasil penelitian mendiskripsikan tentang tidak adanya koordinasi dari pihak pemerintah dalam menerapkan standar untuk dimensi halte di Kota Medan, artinya bahwa keberadaan halte di beberapa ruas jalan di Kota Medan yang tidak lagi berfungsi sebagaimana mestinya.

\section{Tujuan Penelitian}

Penelitian ini memiliki tujuan untuk mengidentifikasi halte dan fasilitas halte di Kota Medan, mencari faktor-faktor yang mempengaruhi penggunaan halte di Kota Medan, menemukan karakteristik penggunaan halte di Kota Medan, dan mengkaji efektifitas penggunaan halte di Kota Medan.

\section{Tinjauan Pustaka}

\section{Pengertian Tempat Pemberhentian Kendaraan Penumpang Umum}

Menurut Direktorat Jenderal Perhubungan Darat (1996), jenis tempat pemberhentian kendaraan penumpang umum (TPKPU) terdiri dari: Tempat henti dengan perlindungan (halte) dan Tempat henti tanpa perlindungan (bus stop).

Halte adalah tempat pemberhentian kendaraan penumpang umum untuk menaikkan/menurunkan penumpang yang dilengkapi dengan bangunan. Tata letak halte pada ruas jalan dapat terlihat pada Gambar 1 berikut:

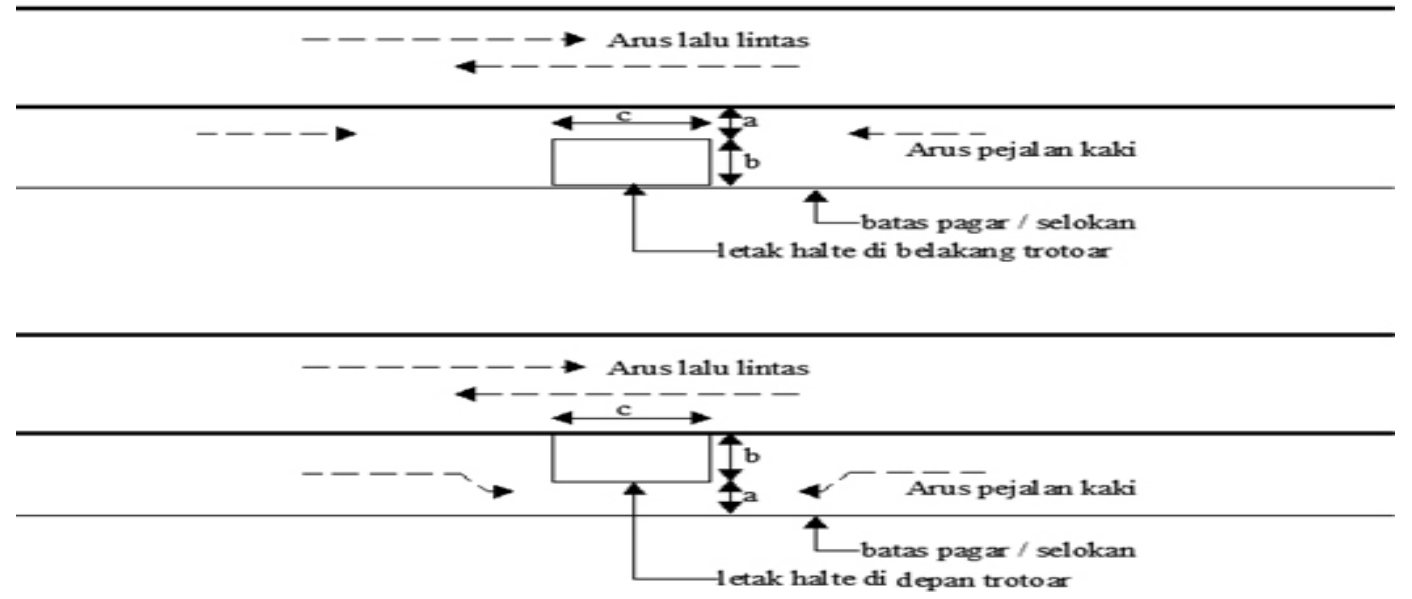

Nilai : $\quad \mathrm{a} \geq 1,5 \mathrm{~m}$ (trotoar), $\mathrm{b} \geq 2 \mathrm{~m}$ (lebar halte), $\mathrm{c} \geq 4 \mathrm{~m}$ (panjang halte)

Gambar 1 Tata Letak Halte Pada Ruas Jalan 
Sedangkan tempat pemberhentian bus adalah tempat untuk menaikkan/menurunkan penumpang tanpa dilengkapi bangunan. Tata letak TPB pada ruas jalan dapat terlihat pada Gambar 2 berikut ini.

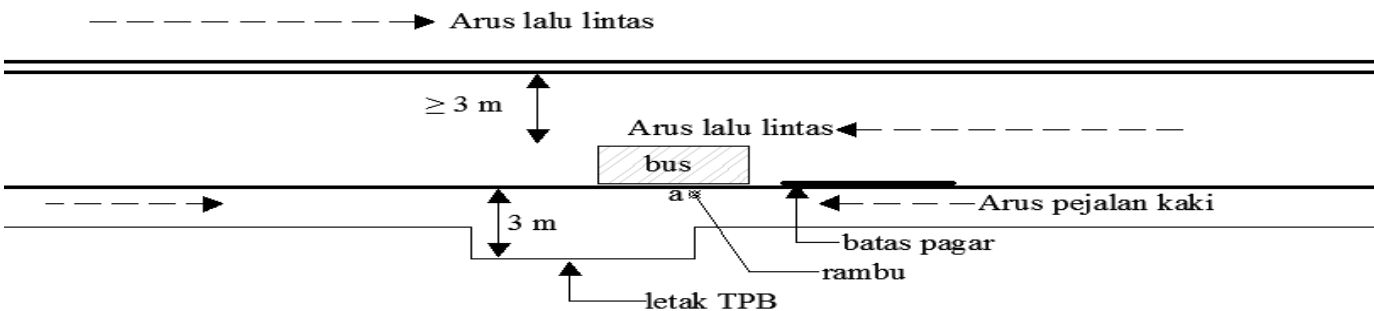

nilai $\mathrm{a}=\min 0,60 \mathrm{~m}$ dari tepi paling luar bahu jalan

Gambar 2. Tata Letak TPB Bus Pada Ruas Jalan

\section{Definisi Halte}

1. Menurut DirJend Bina Marga (1990), halte adalah bagian dari perkerasan jalan tertentu yang digunakan untuk pemberhentian sementara bus dan angkutan penumpang umum lainnya pada waktu menaikkan dan menurunkan penumpang.

2. Menurut DirJend Perhubungan Darat (1996), halte adalah tempat pemberhentian kendaraan penumpang umum untuk menaikkan atau menurunkan penumpang yang dilengkapi dengan bangunan.

3. Menurut LPKM ITB (1997), halte adalah lokasi di mana para penumpang dapat naik/turun dari angkutan umum dan lokasi di mana angkutan umum dapat berhenti untuk menaikkan/ menurunkan penumpang.

\section{Lokasi Halte dan Jarak Halte}

Pedoman praktis menentukan lokasi halte harus memenuhi syarat:

1. Halte terletak pada trotoar dengan ukuran sesuai dengan kebutuhan.

2. Halte diletakkan di muka pusat kegiatan yang membangkitkan pemakai angkutan umum.

3. Halte diletakkan di tempat yang terbuka dan tidak tersembunyi.

\section{Jarak Halte}

Jarak halte adalah jarak antar halte atau disebut juga jarak tempat henti. Berdasarkan keputusan Direktorat Jenderal Perhubungan Darat, tempat henti (halte) dihitung berdasarkan:

1. Kepentingan pengusaha mengacu pada akupansi kendaraan dengan rumus:

$$
\mathrm{S}=\mathrm{V}(\mathrm{nx}+\mathrm{AV})
$$

2. Berdasarkan kepentingan pengusaha dengan mengacu pada performasi kendaraan serta kepentingan pemakai jasa maksimum orang berjalan kaki:

$$
\mathrm{S}=1 / 2\left(\mathrm{X}_{\max }\right)^{2}(1 / \mathrm{a}+1 / \mathrm{b})
$$

Dimana : $\mathrm{S}=$ Jarak tempat henti $(\mathrm{m}), \mathrm{V}=$ Kecepatan/Running speed $(\mathrm{m} / \mathrm{det}), \mathrm{n}=$ Jumlah penumpang di tempat henti (orang), $\mathrm{x}=$ Waktu henti kendaraan menaikkan penumpang (detik), $A=(a+b) /(a \cdot b), a=$ Perlambatan $(\mathrm{m} /$ det $), b=$ Percepatan $(\mathrm{m} /$ det$)$ dan $\mathrm{X}_{\max }=$ Jarak berjalan kaki maksimum (m) 
Berdasarkan faktor-faktor di atas, jarak tempuh henti dapat diatur penempatannya pada Tabel 1 di bawah ini.

Tabel 1 Jarak Halte

\begin{tabular}{|l|l|l|l|}
\hline No. & Tata Guna Lahan & CBD, Pusat Kota & Jarak Tempat \\
\hline 1 & Pusat kegiatan sangat padat: pasar, pertokoan & Kota & $200-300$ \\
\hline 2 & Padat : perkantoran, sekolah, jasa & Kota & $300-400$ \\
\hline 3 & Permukiman & Pinggiran & $300-400$ \\
\hline 4 & Campuran padat : perumahan, sekolah dan jasa & Pinggiran & $300-500$ \\
\hline 5 & Campuran jarang : perumahan, ladang, sawah, tanah kosong & & $500-1000$ \\
\hline
\end{tabular}

Sumber : Departemen Perhubungan, Direktorat Jenderal Perhubungan Darat

\section{Tata Letak Halte Berdasarkan Keputusan Direktorat Jenderal Perhubungan Darat}

Tata letak berdasarkan DirJend. Perhubungan Darat (1996) jarak berjalan yang wajar bagi penumpang angkutan umum untuk daerah CBD 200-400 m, untuk daerah pinggiran kota 300$500 \mathrm{~m}$. Tempat henti (halte) ditentukan oleh jarak, kapasitas dan jumlah permintaan yang dipengaruhi oleh tata guna tanah dan tingkat kepadatan penduduk. Adapun tata letak halte dan TPB terhadap ruang lalu lintas, adalah:

1. Jarak maksimal terhadap fasilitas penyeberangan pejalan kaki adalah $100 \mathrm{~m}$.

2. Jarak minimal halte dari persimpangan adalah $50 \mathrm{~m}$ atau bergantung pada panjang antrian.

3. Jarak minimal gedung (seperti rumah sakit dan tempat ibadah) adalah $100 \mathrm{~m}$.

4. Perletakan di persimpangan adalah farside dan nearside

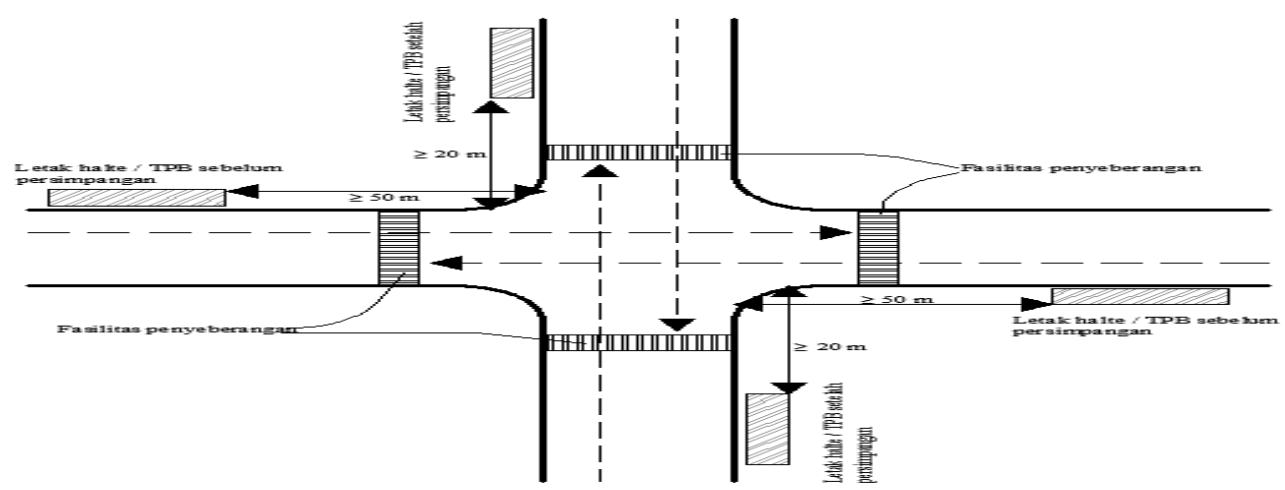

Gambar 3 Perletakan Tempat Henti di Pertemuan Jalan Simpang Empat

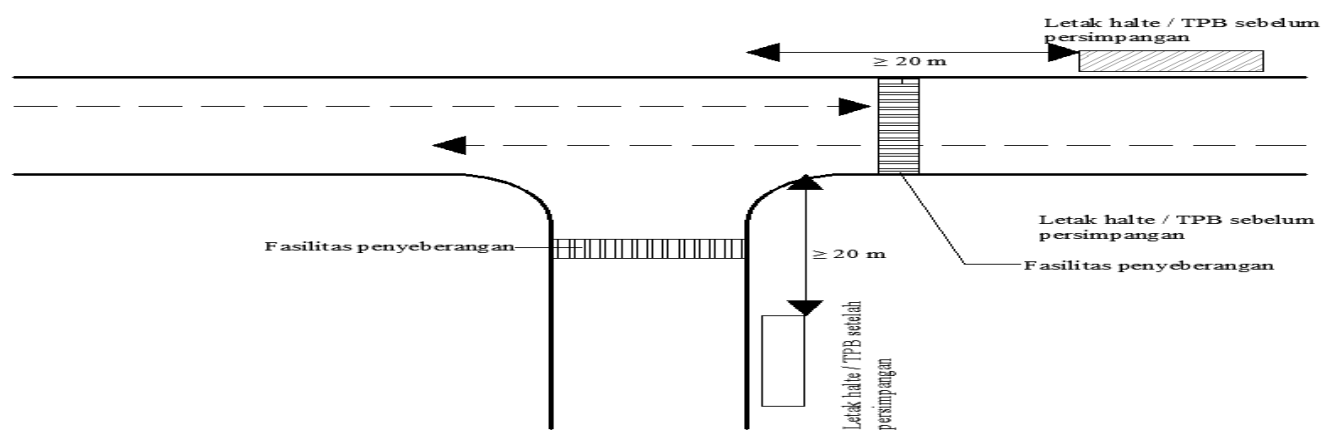

Gambar 4 Perletakan Tempat Henti di Pertemuan Jalan Simpang Tiga 


\section{Jenis Kebijakan Operasional Angkutan Kota}

Tiga jenis kebijakan operasional angkutan kota berkaitan perhentian yaitu:

1. Flag Stop: pengendara atau pengemudi diinstruksikan agar merespon keinginan penumpang kapan sebaiknya bus berhenti, baik untuk menaikkan atau menurunkan penumpang.

2. Set-Stop: pengemudi diwajibkan untuk berhenti di perhentian yang sudah ditetapkan sebelumnya, tidak peduli apakah pada perhentian yang dimaksud ada calon penumpang yang ingin naik ataupun ingin turun.

3. Mixed Stop: merupakan campuran antara flag stops dan set stops.

\section{Tipe Halte}

Secara umum dikenal 3 (tiga) tipe perhentian angkutan umum, yaitu:

1. Curb-side: perhentian yang terletak pada pinggir perkerasan jalan tanpa melakukan perubahan pada perkerasan jalan yang bersangkutan ataupun perubahan pada pedestrian. Lebar minimum untuk side-walk sebesar 2-3 m dimana 1,2-1,5 m digunakan untuk penumpang yang sedang antri menunggu, sedangkan sisanya untuk pedestrian yang lalu lalang.

2. Lay-bay: perhentian yang terletak pada pinggir perkerasan dengan sedikit menjorok ke daerah luar perkerasan. Tipe ini lebih aman dan nyaman dibandingkan dengan curb-side, karena pada lokasi pemberhentian dilakukan pelebaran, sehingga terdapat ruang bebas yang cukup di luar perkerasan jalan bagi manuver masuk, maupun untuk manuver keluar angkutan umum.

3. Bus-bay: perhentian yang dibuat khusus dan terpisah dari perkerasan jalan yang ada menjadi perhentian yang paling ideal, menurut pandang penumpang, pengemudi angkutan umum, maupun bagi lalu lintas lainnya.

Sedangkan menurut Vuchic, VR (1981), ada 3 (tiga) tipe penempatan lokasi halte untuk tempat henti di sepanjang jalan ditinjau dari letak dari persimpangan:

a. Near-side, halte terletak sebelum garis henti persimpangan jalan.

b. Far-side, halte terletak sesudah garis henti di persimpangan jalan.

c. Midblock, halte yang tidak terletak di dekat simpang jalan tetapi masih di salah satu ruas jalan yang terkait dengan simpang jalan tersebut.

Dijelaskan kebutuhan ruang pada tempat henti pada Tabel 2. berikut.

Tabel 2. Kebutuhan Ruang Pada Tempat Henti

\begin{tabular}{|c|c|c|c|c|c|c|}
\hline \multirow{2}{*}{$\begin{array}{l}\text { Panjang } \\
\text { Bus (m) }\end{array}$} & \multicolumn{3}{|c|}{ Satu Tempat Henti $\left(\mathrm{m}^{2}\right)$} & \multicolumn{3}{|c|}{ Dua Tempat Henti $\left(\mathrm{m}^{2}\right)$} \\
\hline & NS & FS & MB & NS & FS & MB \\
\hline 7.50 & 27.5 & 19.5 & 38.0 & 36.0 & 28.0 & 46.5 \\
\hline 9.00 & 29.0 & 21.0 & 39.5 & 39.0 & 31.0 & 49.5 \\
\hline 10.50 & 30.5 & 22.5 & 41.0 & 42.0 & 34.0 & 52.5 \\
\hline 12.00 & 32.0 & 24.0 & 42.5 & 45.0 & 37.0 & 55.5 \\
\hline
\end{tabular}

\section{Fasilitas Halte}

Menurut DirJend. Perhubungan Darat (1996), fasilitas tempat perhentian kendaraan penumpang umum terdiri dari fasilitas utama dan fasilitas tambahan. Adapun fasilitas utama adalah: Identitas halte berupa nama atau nomor, Informasi tentang rute dan jadwal angkutan umum, Tempat henti kendaraan apabila disertai rambu akan lebih aman dan untuk 
melancarkan lalu lintas dapat menggunakan teluk bus (bus lay-bay), Lampu penerangan dan Tempat menunggu penumpang yang tidak mengganggu pejalan kaki dan aman dari lalu lintas. Sedangkan fasilitas tambahan halte: Telepon umum, Tempat sampah, Pagar pengamanan agar pejalan kaki tidak menyeberang di sembarangan tempat dan Papan iklan/pengumuman.

\section{Nilai Efektifitas Penggunaan Halte}

Kajian efektifitas penggunaan halte ditinjau melalui paramater eksisting halte dan perilaku atau persepsi pengguna halte. Parameter eksisting tersebut meliputi tata guna lahan, jarak antar halte, tata letak halte terhadap fasilitas penyeberangan dan dimensi halte. Sedangkan jika ditinjau dari parameter pengguna nilai efektifitas dapat ditentukan dengan rumus:

Nilai efektifitas $(\%)=($ jumlah pengguna halte $/$ jumlah menunggu angkutan umum $) \times 100 \%$

Nilai dan kriteria efektifitas berdasarkan parameter pengguna dapat dilihat pada Tabel 3 berikut ini.

Tabel 3 Nilai Parameter Efektifitas

\begin{tabular}{|l|l|l|}
\hline No. & Nilai Efektifitas $(\%)$ & Kriteria \\
\hline 1 & $0,00-20,00$ & Sangat Tidak Efektif \\
2 & $20,10-40,00$ & Tidak Efektif \\
3 & $40,10-60,00$ & Cukup Efektif \\
4 & $60,10-80,00$ & Efektif \\
5 & $80,10-100,00$ & Sangat Efektif \\
\hline
\end{tabular}

Sumber : Richard Andreas, 2012

\section{Metodologi}

Penelitian ini dilaksanakan dengan kerangka berpikir sebagai berikut:

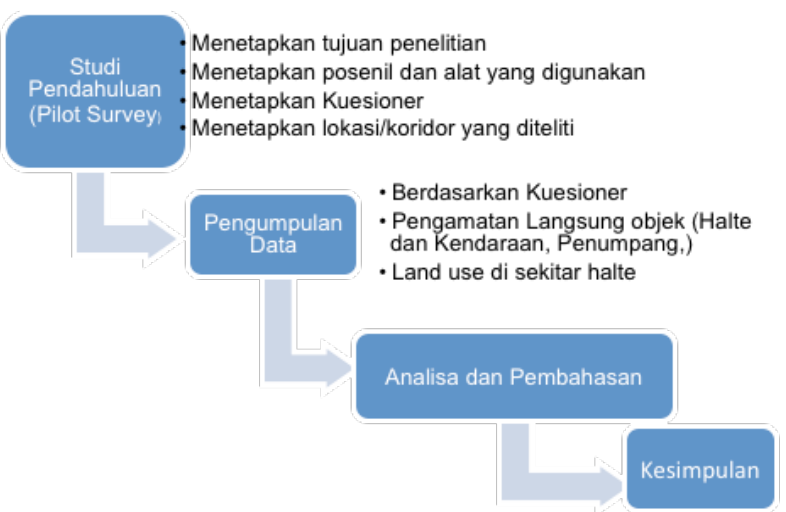

Gambar 1 Kerangka Berpikir Penelitian

\section{Survei Pendahuluan dan Uji Kuesioner}

Survei pendahuluan bertujuan memilih lokasi pengamatan yang tepat sedangkan uji penyebaran kuesioner bertujuan untuk memperoleh gambaran umum seberapa besar responden dapat menerima pernyataan maupun pertanyaan yang diajukan dan berpartisipasi di dalamnya. 


\section{Penentuan Lokasi Penelitian}

Koridor utama lokasi penelitian adalah yakni: Koridor I (Medan-Tanjung Morawa), Koridor II (Medan-Binjai), Koridor III (Medan-Belawan) dan Koridor IV (Medan- Pancur Batu).

\section{Pengambilan Data Lapangan}

Data primer yang dibutuhkan antara lain:

a. Lokasi halte meliputi: Jarak antar halte, Tata letak halte dan Tipe halte

b. Kondisi halte meliputi: Rancang bangun halte dan Fasilitas halte

c. Kuesioner bagi yang menggunakan maupun tidak menggunakan halte dalam menunggu angkutan umum.

Data sekunder yang dikumpulkan adalah jaringan jalan (kondisi ruas jalan dan tata guna lahan sekitar) dan Peraturan-peraturan yang berkaitan.

\section{Penentuan Sampel}

Penarikan sampel halte dilakukan secara non-probability sampling berdasarkan urutan dari anggota populasi yang telah diberi nomor (systematic sampling) menurut Slovin mensyaratkan:

$$
\mathrm{n}=\frac{\mathrm{N}}{1+\mathrm{N}\left(\mathrm{e}^{2}\right)}
$$

Dimana : $\mathrm{n}=$ jumlah sampel, $\mathrm{N}=$ Jumlah populasi dan $\mathrm{e}=$ Presisi yang ditolerir $(1 \%, 5 \%$ dan $10 \%)$ Data primer yang dibutuhkan

\section{Pengolahan dan Penyajian Data}

Data responden yang disajikan antara lain karakteristik responde dan referensi untuk responden. Karakteristik responden terdiri atas Usia, Jenis kelamin, Tingkat pendidikan dan Pekerjaan baik menggunakan dan tidak menggunakan halte. Sementara referensi untuk responden merupakan pertanyaan terhadap responden berupa: Pengetahuan tentang halte, Jarak halte terdekat yang mudah dicapai, Waktu tunggu di halte, Penilaian penempatan dan letak halte, Penilaian kondisi dan fasilitas halte, dan Menggunakan halte/bukan halte.

Dalam penelitian ini, uji validitas koesioner dengan Uji Reliabilitas dan Uji Korelasi Pearson. Nilai $\mathrm{r}$ tabel Pruduct Momen dengan signifikan 5\% $(0,05)$ two tail dengan jumlah $\mathrm{N}$ sebanyak 40 sampel adalah $\mathrm{Df}=\mathrm{N}-2=38$, maka Nilai $\mathrm{r}$ tabel $=0,312$. Validitas suatu kuesioner dapat dinyatakan valid atau tidak valid apabila: rtabel $<$ rhitung dinyatakan valid, sedangkan ketika $\mathrm{r}$ tabel $>\mathrm{r}$ hitung maka dinyatakan tidak valid

Analisis dan pembahasan terhadap data disajikan secara deskriptif kualitatif. Poin yang menjadi pembahasan adalah efektifitas dan faktor-faktor yang mempengaruhi penggunaan halte di Kota Medan.

Tabel 4 Uji Validitas pertanyaan kuesioner

\begin{tabular}{|l|l|l|l|l|}
\hline \multirow{2}{*}{ No } & Pernyataan & \multicolumn{2}{|l|}{ Nilai r } & \multirow{2}{*}{ Validitas } \\
\cline { 3 - 4 } & & tabel & Hitung & \\
\hline 1 & Menggunakan halte/bukan halte & 0,312 & 0,575 & Valid \\
\hline 2 & Pengetahuan tentang halte & 0,312 & 0,326 & Valid \\
\hline 3 & Tujuan perjalanan & 0,312 & 0,104 & Tidak valid \\
\hline
\end{tabular}




\begin{tabular}{|l|l|l|l|l|}
\hline \multirow{2}{*}{ No } & Pernyataan & \multicolumn{2}{|l|}{ Nilai r } & \multirow{2}{*}{ Validitas } \\
\cline { 3 - 4 } & & tabel & Hitung & \\
\hline 4 & Jangkauan ke halte & 0,312 & 0,604 & Valid \\
\hline 5 & Waktu tunggu di halte & 0,312 & 0,732 & Valid \\
\hline 6 & Waktu tunggu bukan di halte & 0,312 & 0,081 & tidak valid \\
\hline 7 & Penempatan halte & 0,312 & 0,691 & Valid \\
\hline 8 & Fasilitas halte & 0,312 & 0,675 & Valid \\
\hline
\end{tabular}

\section{Lokasi Penelitian}

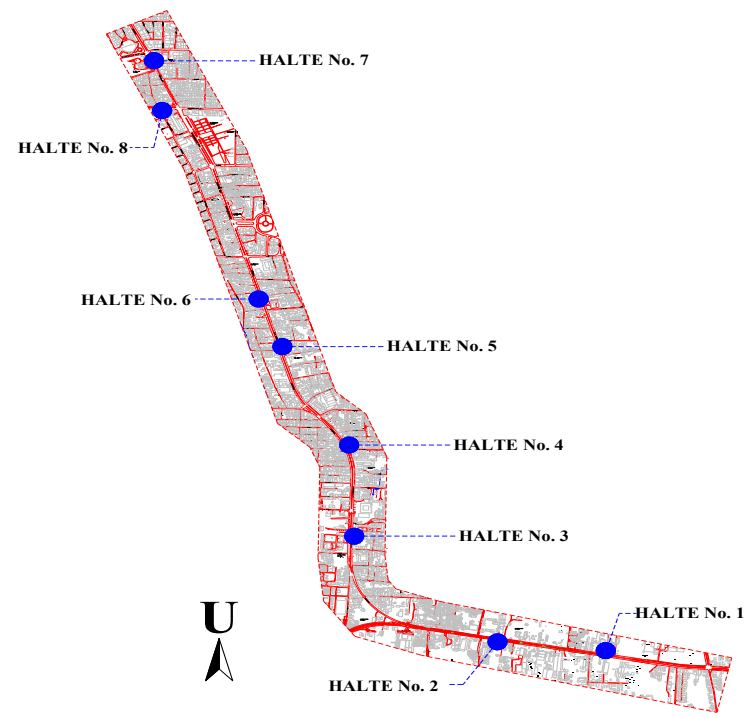

Gambar 2 Letak Halte Pada Ruas Jalan Koridor I (Medan-Tj. Morawa)

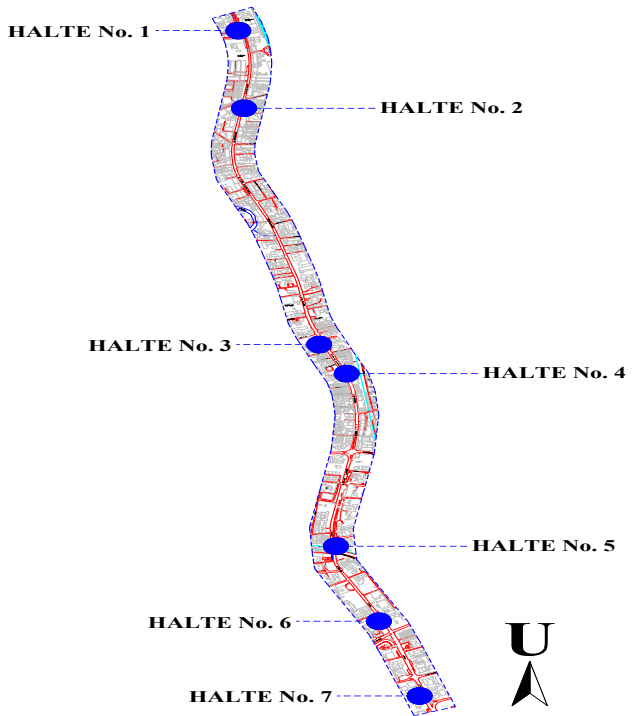

Gambar 3. Letak Halte Pada Ruas Jalan Koridor III (Medan-Belawan) 


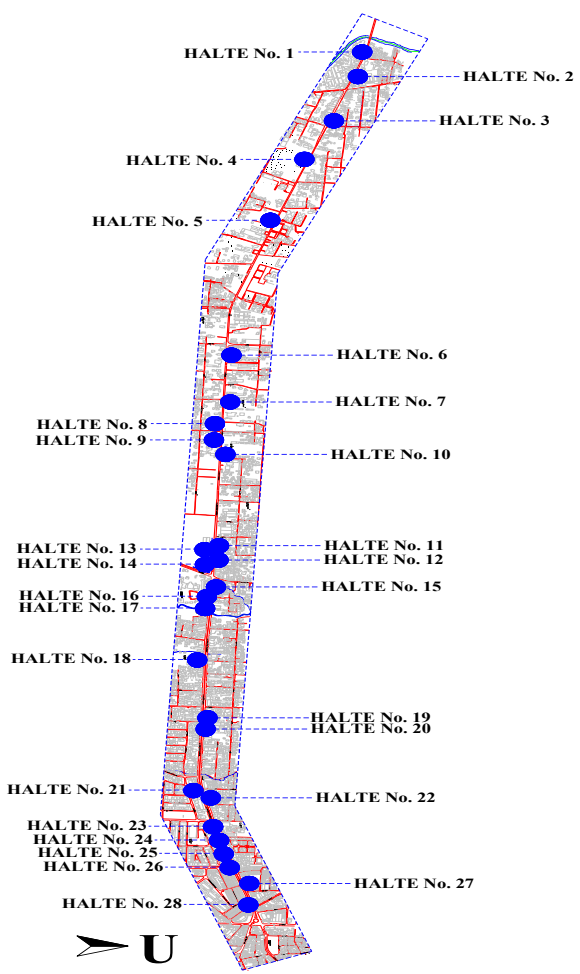

Gambar 4 Sketsa Letak Halte Pada Ruas Jalan Koridor II (Medan-Binjai)

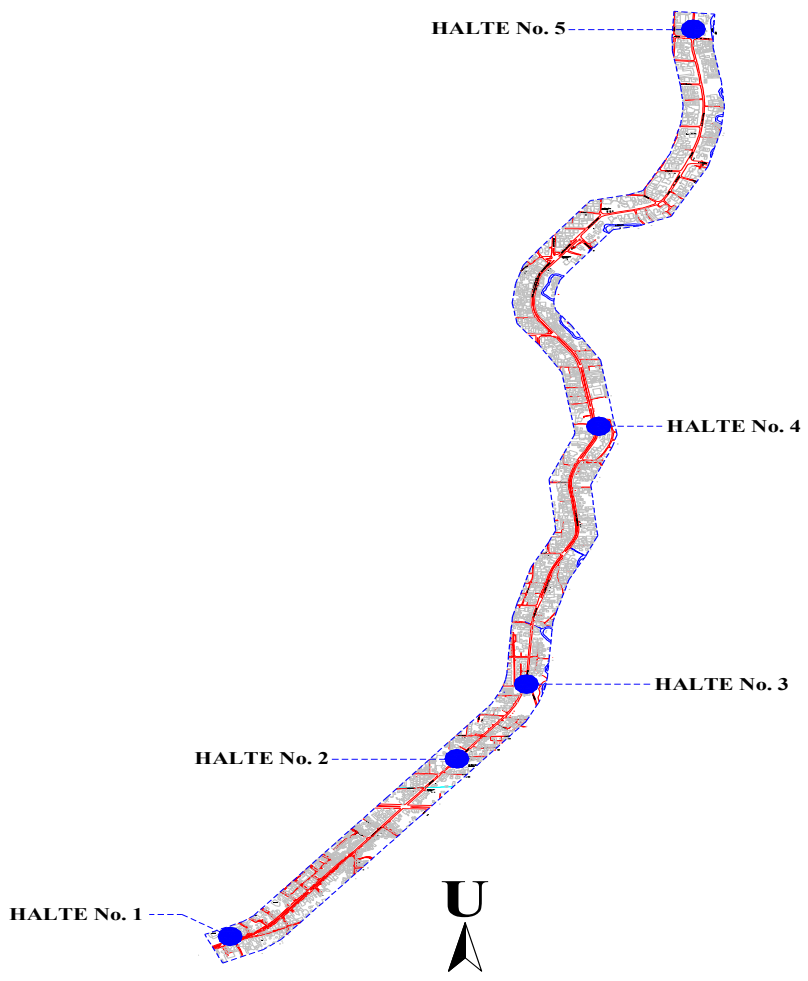

Gambar 5 Letak Halte Pada Ruas Jalan Koridor IV (Medan-Pancur Batu) 


\section{Analisis dan Pembahasan}

Letak Halte, Tata Guna Lahan, Dimensi, Fasilitas, Tipe dan Fasilitas Jalan

Tabel 5 Rekapitulasi Letak Halte, Tata Guna Lahan, Dimensi, Fasilitas, Tipe dan Fasilitas Jalan

\begin{tabular}{|c|c|c|c|c|c|c|c|c|c|c|c|c|c|c|c|c|c|}
\hline \multirow[b]{2}{*}{$\begin{array}{l}\text { Kori- } \\
\text { dor }\end{array}$} & \multirow[b]{2}{*}{$\begin{array}{l}\text { No. } \\
\text { Halte }\end{array}$} & \multirow[b]{2}{*}{ Letak Halte } & \multirow[b]{2}{*}{ Ruas Jalan } & \multirow[b]{2}{*}{ Tata Guna Lahan } & \multirow[b]{2}{*}{ Dimensi } & \multicolumn{8}{|c|}{ Fasilitas Halte } & \multicolumn{2}{|c|}{ Tipe Halte } & \multicolumn{2}{|c|}{ Fasilitas Pejalan } \\
\hline & & & & & & $\begin{array}{l}\text { Ident } \\
\text { itas }\end{array}$ & Rambu & $\begin{array}{l}\text { Info } \\
\text { Tray } \\
\text { ek }\end{array}$ & Lampu & $\begin{array}{c}\text { Tem } \\
\text { pat } \\
\text { Dud } \\
\text { uk }\end{array}$ & $\begin{array}{l}\text { Tempat } \\
\text { Sampah }\end{array}$ & Pagar & $\begin{array}{c}\text { Papa } \\
\text { n } \\
\text { Iklan } \\
\end{array}$ & Perhentian & Simpang & Sidewalk & $\begin{array}{l}\text { Penyeberan } \\
\text { gan }\end{array}$ \\
\hline \multirow{6}{*}{$-\frac{\dot{\mathrm{s}}}{\mathrm{s}}$} & 1 & Sekolah Parulian 3 & Jl. SM. Rraja & Sekolah & $7 \times 1,8 \mathrm{~m}$ & $\mathrm{X}$ & $\mathrm{X}$ & $\mathrm{X}$ & $\mathrm{X}$ & $\sqrt{ }$ & $\mathrm{X}$ & $\mathrm{X}$ & $\mathrm{X}$ & Curb-side & Far-side & Tidak Ada & Tidak Ada \\
\hline & 2 & Loket Bus ALS & Jl.SM. Raja & Layanan & $8,1 \times 2 \mathrm{~m}$ & $\mathrm{x}$ & $\mathrm{x}$ & $\mathrm{x}$ & $\sqrt{ }$ & $\sqrt{ }$ & $\mathrm{x}$ & $\mathrm{x}$ & $\mathrm{x}$ & Curb-side & Mid-block & Depan & Tidak Ada \\
\hline & 4 & Universitas Alwasliyah & Jl. SM. Raja & Angkutan & $7,9 \times 2 \mathrm{~m}$ & $\mathrm{x}$ & $\mathrm{x}$ & $\mathrm{x}$ & $\mathrm{x}$ & $\sqrt{ }$ & $\sqrt{ }$ & $\mathrm{x}$ & $\mathrm{x}$ & Curb-side & Mid-block & Belakang & Tidak Ada \\
\hline & 5 & SPBU 14.202 .102 & Jl. SM. Raja & Sekolah & $70 \times 1,6 \mathrm{~m}$ & $\mathrm{X}$ & $\mathrm{x}$ & $\mathrm{x}$ & $\mathrm{x}$ & $\sqrt{ }$ & $\mathrm{x}$ & $\mathrm{X}$ & $\sqrt{ }$ & Curb-side & Near-side & Tidak Ada & Tidak Ada \\
\hline & 7 & Yuki Sp Raya - & Jl. SM. Raja & Layanan Publik & $8 \times 1,6 \mathrm{~m}$ & $\mathrm{x}$ & $\mathrm{x}$ & $\mathrm{x}$ & $\mathrm{x}$ & $\sqrt{ }$ & $\mathrm{x}$ & $\mathrm{x}$ & $\sqrt{ }$ & Curb-side & Near-side & Belakang & $\mathrm{PPO}$ \\
\hline & 8 & Sp Jl. Ir. H. Juanda & Jl. Ir. H. Juanda & $\begin{array}{l}\text { Perbelanjaan } \\
\text { Pertokoan }\end{array}$ & $7 \times 1,6 \mathrm{~m}$ & $\mathrm{x}$ & $\mathrm{x}$ & $\mathrm{x}$ & $\mathrm{x}$ & $\sqrt{ }$ & $\mathrm{x}$ & $\mathrm{x}$ & $\sqrt{ }$ & Curb-side & Far-side & Tidak Ada & Zebra Cross \\
\hline \multirow{20}{*}{ 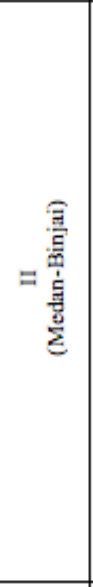 } & 1 & Pasar Lalang I & Jl. G. Subroto & Pasar & $5,1 \times 2 \mathrm{~m}$ & $\sqrt{1}$ & $\sqrt{ }$ & $\sqrt{ }$ & $\mathrm{X}$ & $\sqrt{ }$ & $\mathrm{X}$ & $\sqrt{ }$ & $\mathrm{X}$ & Curb-side & Near-side & Belakang & Zebra Cross \\
\hline & 2 & Pasar Lalang II & Jl. G Subroto & Pasar & $5,1 \times 2 \mathrm{~m}$ & $\sqrt{ }$ & $\sqrt{ }$ & $\sqrt{ }$ & $\mathrm{x}$ & $\sqrt{ }$ & $\mathrm{x}$ & $\sqrt{ }$ & $\mathrm{x}$ & Curb-side & Far-side & Belakang & Zebra Cross \\
\hline & 4 & Lotte Mart & Jl. G Subroto & Perbelanjaan & $5,4 \times 1,5 \mathrm{~m}$ & $\mathrm{x}$ & $\mathrm{x}$ & $\mathrm{x}$ & $\mathrm{X}$ & $\checkmark$ & $\mathrm{x}$ & $\mathrm{X}$ & $\mathrm{x}$ & Curb-side & Mid-block & Depan & Tidak Ada \\
\hline & 5 & S Pekerja Sucofindo & Jl. G Subroto & Kantor \& Toko & $7 \times 1,4 \mathrm{~m}$ & $\mathrm{x}$ & $\mathrm{x}$ & $\mathrm{x}$ & $\mathrm{x}$ & $\sqrt{ }$ & $\mathrm{x}$ & $\mathrm{x}$ & $\mathrm{x}$ & Curb-side & Mid-block & Tidak Ada & Tidak Ada \\
\hline & 7 & PRSU & Jl. G Subroto & Layanan Publik & $5,5 \times 1,5 \mathrm{~m}$ & $\mathrm{x}$ & $\mathrm{x}$ & $\mathrm{x}$ & $\mathrm{x}$ & $\sqrt{ }$ & $\mathrm{x}$ & $\mathrm{X}$ & $\mathrm{x}$ & Curb-side & Near-side & Depan & Tidak Ada \\
\hline & 8 & YP. Budi Luhur & Jl. G Subroto & Sekolah & $7,5 \times 1,4 \mathrm{~m}$ & $\sqrt{ }$ & $\mathrm{x}$ & $\mathrm{X}$ & $\mathrm{x}$ & $\sqrt{ }$ & $\mathrm{x}$ & $\mathrm{x}$ & $\mathrm{x}$ & Curb-side & Far-side & Depan & Tidak Ada \\
\hline & 10 & RRI & Jl. G Subroto & Layanan Berita & $7 \times 1,6 \mathrm{~m}$ & $\checkmark$ & $\mathrm{x}$ & $\mathrm{x}$ & $\mathrm{x}$ & $\checkmark$ & $\mathrm{X}$ & $\mathrm{x}$ & $\mathrm{x}$ & Curb-side & Mid-block & Depan & Tidak Ada \\
\hline & 11 & Pasar Sei Kambing & Jl. G Subroto & Pasar & $7 \times 1,6 \mathrm{~m}$ & $\mathrm{x}$ & $\mathrm{X}$ & $\mathrm{x}$ & $\mathrm{x}$ & $\sqrt{ }$ & $\mathrm{X}$ & $\mathrm{x}$ & $\mathrm{x}$ & Curb-side & Near-side & Depan & Zebra Cross \\
\hline & 13 & P.Tomang Elok & Jl. G Subroto & Perumahan & $7 \times 2 \mathrm{~m}$ & $\sqrt{ }$ & $\mathrm{X}$ & $\mathrm{X}$ & $\mathrm{X}$ & $\sqrt{ }$ & $\mathrm{x}$ & $\sqrt{ }$ & $\mathrm{x}$ & Curb-side & Far-side & Depan & Zebra Cross \\
\hline & 14 & P.Tomang Elok & Jl. G Subroto & Perumahan & $8 \times 1,6 \mathrm{~m}$ & $\mathrm{x}$ & $\mathrm{X}$ & $\mathrm{x}$ & $\mathrm{X}$ & $\sqrt{ }$ & $\mathrm{X}$ & $\mathrm{X}$ & $\mathrm{x}$ & Curb-side & Far-side & Depan & Zebra Cross \\
\hline & 16 & Univ. Panca Budi & Jl. G Subroto & Sekolah & $5,1 \times 2 \mathrm{~m}$ & $\sqrt{ }$ & $\mathrm{X}$ & $\mathrm{X}$ & $\mathrm{x}$ & $\sqrt{ }$ & $\mathrm{x}$ & $\sqrt{ }$ & $\mathrm{x}$ & Curb-side & Near-side & Tidak Ada & Tidak Ada \\
\hline & 17 & Univ. Panca Budi & Jl. G Subroto & Sekolah & $7,1 \times 1,6 \mathrm{~m}$ & $\sqrt{ }$ & $\mathrm{x}$ & $\mathrm{X}$ & $\mathrm{X}$ & $\sqrt{ }$ & $\sqrt{ }$ & $\mathrm{X}$ & $\sqrt{ }$ & Curb-side & Near-side & Tidak Ada & Tidak Ada \\
\hline & 19 & Berastagi Swalayan & Jl. G Subroto & Perbelanjaan & $6,2 \times 1,5 \mathrm{~m}$ & $\mathrm{x}$ & $\mathrm{x}$ & $\mathrm{x}$ & $\mathrm{X}$ & $\sqrt{ }$ & $\mathrm{X}$ & $\mathrm{X}$ & $\sqrt{ }$ & Curb-side & Mid-block & Tidak Ada & Tidak Ada \\
\hline & 20 & Berastagi Swalayan & Jl. G Subroto & Perbelanjaan & $7,25 \times 1,2$ & $\mathrm{x}$ & $\mathrm{x}$ & $\mathrm{x}$ & $\mathrm{X}$ & $\sqrt{ }$ & $\mathrm{X}$ & $\mathrm{x}$ & $\sqrt{ }$ & Curb-side & Mid-block & Belakang & Tidak Ada \\
\hline & 22 & Y.P. Mardi Lestari & Jl. G Subroto & Sekolah & $5,1 \times 2 \mathrm{~m}$ & $\sqrt{ }$ & $\sqrt{ }$ & $\sqrt{ }$ & $\mathrm{X}$ & $\sqrt{ }$ & $\mathrm{x}$ & $\sqrt{ }$ & $\mathrm{x}$ & Curb-side & Mid-block & Belakang & Tidak Ada \\
\hline & 23 & Plaza Medan Fair & Jl. G Subroto & Perbelanjaan & $4,8 \times 2 \mathrm{~m}$ & $\mathrm{X}$ & $\mathrm{X}$ & $\mathrm{x}$ & $\mathrm{x}$ & $\sqrt{ }$ & $\mathrm{X}$ & $\mathrm{X}$ & $\sqrt{ }$ & Curb-side & Near-side & Tidak Ada & PPO \\
\hline & 24 & Plaza Medan Fair & Jl. G Subroto & Perbelanjaan & $6,2 \times 1,5 \mathrm{~m}$ & $\mathrm{x}$ & $\mathrm{X}$ & $\mathrm{x}$ & $\mathrm{X}$ & $\sqrt{ }$ & $\mathrm{X}$ & $\mathrm{x}$ & $\sqrt{ }$ & Curb-side & Near-side & Tidak Ada & IPO \\
\hline & 25 & Plaza Medan Fair & Jl. G Subroto & Perbelanjaan & $6,2 \times 1,5 \mathrm{~m}$ & $\mathrm{X}$ & $\mathrm{X}$ & $\mathrm{x}$ & $\mathrm{X}$ & $\sqrt{ }$ & $\mathrm{x}$ & $\mathrm{X}$ & $\sqrt{ }$ & Curb-side & Near-side & Tidak Ada & IPO \\
\hline & 26 & Plaza Medan Fair & Jl. G Subroto & Perbelanjaan & $6 \times 1,6 \mathrm{~m}$ & $\mathrm{x}$ & $\mathrm{X}$ & $\mathrm{x}$ & $\mathrm{X}$ & $\sqrt{ }$ & $\mathrm{X}$ & $\mathrm{X}$ & $\mathrm{X}$ & Curb-side & Mid-block & Belakang & PPO \\
\hline & 28 & Bank OCBC NISP & Jl. G Subroto & Layanan Bank & $6 \times 1,6 \mathrm{~m}$ & $\mathrm{X}$ & $\mathrm{X}$ & $\mathrm{x}$ & $\mathrm{X}$ & $\sqrt{ }$ & $\mathrm{X}$ & $\mathrm{x}$ & $\mathrm{X}$ & Curb-side & Far-side & Belakang & JPO \\
\hline \multirow{5}{*}{ 自弯总 } & 1 & SPBU 14.202.113 & Jl. Yos Sudarso & Lay. Publik & $6 \times 1,5 \mathrm{~m}$ & $\mathrm{X}$ & $\mathrm{X}$ & $\mathrm{X}$ & $\mathrm{X}$ & $\sqrt{1}$ & $\mathrm{X}$ & $\mathrm{X}$ & $\mathrm{X}$ & Curb-side & Far-side & Depan & Zebra Cross \\
\hline & 2 & Pasar Brayan & Jl. Yos Sudarso & Pasar & $7 \times 1,5 \mathrm{~m}$ & $\mathrm{x}$ & $\mathrm{X}$ & $\mathrm{x}$ & $\mathrm{x}$ & $\sqrt{ }$ & $\mathrm{x}$ & $\mathrm{X}$ & $\mathrm{x}$ & Curb-side & Mid-block & Belakang & Tidak Ada \\
\hline & 4 & Sekolah Metodist 8 & Jl. Yos Sudarso & Sekolah & $8 \times 2 \mathrm{~m}$ & $\mathrm{x}$ & $\mathrm{X}$ & $\mathrm{X}$ & $\mathrm{x}$ & $\sqrt{ }$ & $\mathrm{x}$ & $\mathrm{X}$ & $\mathrm{x}$ & Curb-side & Mid-block & Depan & Tidak Ada \\
\hline & 5 & Rafindo Dig.Printing & Jl. Putri Hijau & Rumah\&Toko & $8 \times 1,5 \mathrm{~m}$ & $\mathrm{x}$ & $\mathrm{x}$ & $\mathrm{X}$ & $\mathrm{x}$ & $\sqrt{ }$ & $\mathrm{x}$ & $\mathrm{X}$ & $\mathrm{x}$ & Curb-side & Near-side & Depan & Zebra Cross \\
\hline & 7 & Kantor Pos & Jl. Balai Kota & Lay Publik & $7 \times 1,5 \mathrm{~m}$ & $\mathrm{x}$ & $\mathrm{x}$ & $\mathrm{X}$ & $\mathrm{X}$ & $\sqrt{ }$ & $\mathrm{X}$ & $\mathrm{X}$ & $\mathrm{x}$ & Curb-side & Mid-block & Tidak Ada & JPO \\
\hline \multirow{4}{*}{ 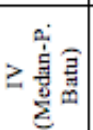 } & 1 & Y.P. Darma Bakti & J1. Jamin Ginting & Sekolah & $8 \times 1,4 \mathrm{~m}$ & $\mathrm{X}$ & $\mathrm{X}$ & $\mathrm{X}$ & $\mathrm{X}$ & $\sqrt{1}$ & $\mathrm{X}$ & $\mathrm{X}$ & $\mathrm{X}$ & \begin{tabular}{|l|} 
Curb-side \\
\end{tabular} & Mid-block & Tidak Ada & Tidak Ada \\
\hline & 3 & Sp Jl. Sembada & Jl. Jamin Ginting & Kantor & $6,2 \times 1,2 \mathrm{~m}$ & $\mathrm{x}$ & $\mathrm{x}$ & $\mathrm{x}$ & $\mathrm{x}$ & $\mathrm{x}$ & $\mathrm{x}$ & $\mathrm{x}$ & $\mathrm{x}$ & Curb-side & Mid-block & Depan & Tidak Ada \\
\hline & 4 & SDN No. 060885 & Jl. Jamin Ginting & Sckolah & $6,2 \times 1,2 \mathrm{~m}$ & $\mathrm{x}$ & $\mathrm{x}$ & $\mathrm{x}$ & $\mathrm{x}$ & $\sqrt{ }$ & $\mathrm{X}$ & $\mathrm{x}$ & $\mathrm{x}$ & Curb-side & Mid-block & Tidak Ada & Tidak Ada \\
\hline & 5 & Cambridge & Jl. S. Parman & Hotel & $6,5 \times 1,5 \mathrm{~m}$ & $\mathrm{x}$ & $\mathrm{x}$ & $\mathrm{x}$ & $\mathrm{x}$ & $\sqrt{ }$ & $\mathrm{X}$ & $\mathrm{x}$ & $\sqrt{ }$ & Curb-side & Far-side & Tidak Ada & Tidak Ada \\
\hline
\end{tabular}


JURnal ReKayasa KonstruKSI MEKaNiKa SiPIL

Vol. 2 No.1, Maret 2019

ISSN 2614-5707 (cetak)

Tabel 6 Rekapitulasi Karakteristik dan Persepsi Responden

\begin{tabular}{|c|c|c|c|c|c|c|c|}
\hline No. & & $\begin{array}{c}\text { Karakteristik } \\
\text { Persepsi Responden }\end{array}$ & $\begin{array}{c}\text { Koridor I } \\
\text { (Jl. Sisingamangaraja-Jl. H. } \\
\text { Juanda) }\end{array}$ & $\begin{array}{c}\text { Koridor II } \\
\text { (Jl. Gatot Subroto) }\end{array}$ & $\begin{array}{c}\text { Koridor III } \\
\text { (Jl. Yos Sudarso-Jl. Putri } \\
\text { Hijau- Jl. Balai Kota) }\end{array}$ & $\begin{array}{c}\text { Koridor IV } \\
\text { (Jl. Jamin Ginting-Jl. S. } \\
\text { Parman) }\end{array}$ & $\begin{array}{c}\text { Kota Medan } \\
\text { (Gabungan Seluruh } \\
\text { Koridor) } \\
\end{array}$ \\
\hline 1 & \multirow{6}{*}{ 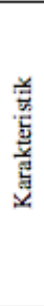 } & Jumlah & 47 Responden & 155 Responden & 39 Responden & 31 Responden & 272 Responden \\
\hline 2 & & Persentase & $31,91 \%$ & $34,19 \%$ & $30,77 \%$ & $35,48 \%$ & $33,46 \%$ \\
\hline 3 & & Jenis Kelamin & $\begin{array}{l}\text { Pria }=8,51 \% \\
\text { Wanita }=23,40 \%\end{array}$ & $\begin{array}{l}\text { Pria }=10,96 \% \\
\text { Wanita }=23,23 \%\end{array}$ & $\begin{array}{l}\text { Pria }=5,13 \% \\
\text { Wanita }=25,64 \%\end{array}$ & $\begin{array}{l}\text { Pria }=9,67 \% \\
\text { Wanita }=25,81 \%\end{array}$ & $\begin{array}{l}\text { Pria }=9,57 \% \\
\text { Wanita }=23,89 \%\end{array}$ \\
\hline 4 & & Usia Terbanyak & $16-20$ th $=12,77 \%$ & $16-20$ th $=15,48 \%$ & $21-25$ th $=15,38 \%$ & $16-20$ th $=16,13 \%$ & $16-20$ th $=13,60 \%$ \\
\hline 5 & & Tingkat Pendidikan & $\mathrm{SMA}=17,02 \%$ & $\mathrm{SMA}=20,65 \%$ & Sarjana $=15,38 \%$ & $\mathrm{SMA}=22,58 \%$ & $\mathrm{SMA}=18,75 \%$ \\
\hline 6 & & Profesi & $\begin{array}{l}\text { Pelajar dan Mahasiswa } \\
=19,15 \%\end{array}$ & $\begin{array}{l}\text { Pelajar dan Mahasiswa } \\
=19,35 \%\end{array}$ & $\begin{array}{l}\text { Pegawai Swasta } \\
=12,82 \%\end{array}$ & $\begin{array}{l}\text { Pelajar dan Mahasiswa } \\
=22,58 \%\end{array}$ & $\begin{array}{l}\text { Pelajar dan Mahasiswa } \\
=29,04 \%\end{array}$ \\
\hline 7 & \multirow{5}{*}{ 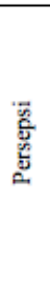 } & Pengetahuan & $\begin{array}{l}\text { Lokasi Menunggu Angkutan } \\
\text { Umum } \\
=65,96 \%\end{array}$ & $\begin{array}{l}\text { Lokasi Menunggu Angkutan } \\
\text { Umum } \\
=70,97 \%\end{array}$ & $\begin{array}{l}\text { Lokasi Menunggu } \\
\text { Angkutan Umum } \\
=76,92 \%\end{array}$ & $\begin{array}{l}\text { Lokasi Menunggu } \\
\text { Angkutan Umum } \\
=64,52 \%\end{array}$ & $\begin{array}{l}\text { Lokasi Menunggu } \\
\text { Angkutan Umum } \\
=70,22 \%\end{array}$ \\
\hline 8 & & Jangkauan & $200 \mathrm{~m}-400 \mathrm{~m}=29,79 \%$ & $\begin{array}{cl}200 & \mathrm{~m}-400 \mathrm{~m}= \\
& 29,03 \%\end{array}$ & $>400 \mathrm{~m}=43,59 \%$ & $200 \mathrm{~m}-400 \mathrm{~m}=29,03 \%$ & $>400 \mathrm{~m}=30,15 \%$ \\
\hline 9 & & Waktu Tunggu & $15-30$ menit $=40,43 \%$ & $15-30$ menit $=35,48 \%$ & $15-30$ menit $=35,90 \%$ & 15 menit $<=38,71 \%$ & $15-30$ menit $<=36,76 \%$ \\
\hline 10 & & Penilaian Letak/Penempatan & Cukup Setuju $=34,04 \%$ & $\begin{array}{l}\text { Sangat Tidak Setuju } \\
=27,74 \%\end{array}$ & $\begin{array}{l}\text { Sangat Tidak Setuju } \\
=30,77 \%\end{array}$ & Cukup Setuju $=41,94 \%$ & Cukup Setuju = 30,88\% \\
\hline 11 & & Penilaian Fasilitas Halte & Tidak Baik $=46,81 \%$ & Tidak Baik $=40,65 \%$ & Tidak Baik $=64,90 \%$ & Tidak Baik $=41,94 \%$ & Tidak Baik $=45,22 \%$ \\
\hline
\end{tabular}

\section{Kajian Efektifitas Penggunaan Halte di Kota Medan}

Dalam mengkaji efektifitas penggunaan halte dapat ditinjau melalui paramater eksisting halte dan prilaku atau persepsi penguna halte. Parameter efektifitas penggunaan halte dapat diuraikan pada tabel berikut ini.

Tabel 7 Kajian Efektifitas Penggunaan Halte

\begin{tabular}{|c|c|c|c|c|c|c|c|c|c|c|c|c|c|c|c|c|c|c|c|}
\hline \multirow{3}{*}{\multicolumn{2}{|c|}{ No. Halte }} & \multicolumn{15}{|c|}{ Paramater Eksisting Halte } & \multicolumn{3}{|c|}{ Parameter Pengguna } \\
\hline & & \multirow[b]{2}{*}{ Tata Guna Lahan } & \multirow{2}{*}{\multicolumn{2}{|c|}{$\begin{array}{c}\text { Jarak Antar } \\
\text { Halte }\end{array}$}} & \multicolumn{3}{|c|}{ Jarak Halte Terhadap } & \multirow{2}{*}{\multicolumn{8}{|c|}{ Fasilitas Halte }} & \multirow[b]{2}{*}{$\begin{array}{l}\text { Dimensi } \\
\text { Halte }\end{array}$} & \multirow{2}{*}{$\begin{array}{c}\text { Jumlah } \\
\text { Menunggu } \\
\text { Angkutan }\end{array}$} & \multirow{2}{*}{$\begin{array}{c}\text { Jumlah } \\
\text { Pengguna } \\
\text { Halte }\end{array}$} & \multirow{2}{*}{$\begin{array}{c}\text { Kajian } \\
\text { Efektifitas }\end{array}$} \\
\hline & & & & & \multirow{2}{*}{\multicolumn{2}{|c|}{$\begin{array}{l}\text { Fasilitas Pejalan Kaki } \\
\text { Jarak maksimal terhadap } \\
\text { fasilitas penyeberangan } \\
\text { pejalan kaki (Zebra Cross } \\
\text { dan JPO) adalah } 100 \mathrm{~m}\end{array}$}} & Persimpangan & & & & & & & & & & & & \\
\hline \multirow{2}{*}{\multicolumn{2}{|c|}{$\begin{array}{l}\text { Syarat dan } \\
\text { Ketentuan }\end{array}$}} & \multicolumn{3}{|c|}{$\begin{array}{l}\text { Pusat kegiatan sangat padat : pasar, } \\
\text { pertokoan }=200-300 \mathrm{~m} \\
\text { Padat : perkantoran, sekolah, jasa, } \\
\text { pemukiman }=300-400 \mathrm{~m} \\
\text { Campuran padat : perumahan, } \\
\text { layanan publik dan jasa }=300-500 \mathrm{~m}\end{array}$} & & & $\begin{array}{l}\text { Jarak minimal } \\
\text { halte dari } \\
\text { persimpangan } \\
\text { adalah } 50 \mathrm{~m}\end{array}$ & \multicolumn{8}{|c|}{$\begin{array}{ll}\text { 1. } & \text { Identitas } \\
\text { 2. } & \text { Rambu } \\
\text { 3. } & \text { Info Trayek } \\
\text { 4. } & \text { Lampu Penerangan } \\
\text { 5. } & \text { Tempat Duduk } \\
\text { 6. } & \text { Tempat Sampah } \\
\text { 7. } & \text { Pagar Pembatas } \\
\text { 8. } & \text { Papan Iklan } \\
\end{array}$} & $\begin{array}{l}\geq 4 \mathrm{~m} \\
\mathrm{x} \\
\geq 2 \mathrm{~m}\end{array}$ & & \multicolumn{2}{|c|}{ Nilai efektifitas (\%) } \\
\hline & & & $\begin{array}{c}\text { Sebel } \\
\text { um }\end{array}$ & Berikut & $\begin{array}{l}\text { Side } \\
\text { Walk }\end{array}$ & $\begin{array}{c}\text { Penye- } \\
\text { berangan }\end{array}$ & & 1 & 2 & 3 & 4 & 5 & 6 & 7 & 8 & & & & \\
\hline \multirow{4}{*}{ 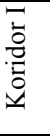 } & 1 & Sekolah & - & $\mathrm{x}$ & $\mathrm{x}$ & $\mathrm{x}$ & $\sqrt{ }$ & $\mathrm{x}$ & $\mathrm{x}$ & $\mathrm{x}$ & $\mathrm{x}$ & $\sqrt{ }$ & $\mathrm{x}$ & $\mathrm{x}$ & $\mathrm{x}$ & $\mathrm{x}$ & \multirow[t]{4}{*}{47 orang } & \multirow[t]{4}{*}{15 orang } & \multirow{4}{*}{$\begin{array}{l}= \\
31,91 \% \\
\text { Tidak } \\
\text { Efektif }\end{array}$} \\
\hline & 2 & Layanan Publik & $\sqrt{ }$ & $\mathrm{x}$ & $\sqrt{ }$ & $\mathrm{x}$ & $\sqrt{ }$ & $\mathrm{x}$ & $\mathrm{x}$ & $\mathrm{x}$ & $\sqrt{ }$ & $\sqrt{ }$ & $\mathrm{x}$ & $\mathrm{x}$ & $\mathrm{x}$ & $\sqrt{ }$ & & & \\
\hline & 4 & Sekolah & $\mathrm{x}$ & $\mathrm{x}$ & $\sqrt{ }$ & $\mathrm{x}$ & $\sqrt{ }$ & $\mathrm{x}$ & $\mathrm{x}$ & $\mathrm{x}$ & $\mathrm{x}$ & $\sqrt{ }$ & $\sqrt{ }$ & $\mathrm{x}$ & $\mathrm{x}$ & $\sqrt{ }$ & & & \\
\hline & 5 & Layanan Publik & $\mathrm{x}$ & $\sqrt{ }$ & $\mathrm{x}$ & $\mathrm{x}$ & $\sqrt{ }$ & $\mathrm{x}$ & $\mathrm{x}$ & $\mathrm{x}$ & $\mathrm{x}$ & $\sqrt{ }$ & $\mathrm{x}$ & $\mathrm{x}$ & $\sqrt{ }$ & $\mathrm{x}$ & & & \\
\hline
\end{tabular}


JuRnal Rekayasa Konstruksi Mekanika SipiL

Vol. 2 No.1, Maret 2019 ISSN 2614-5707 (cetak)

\begin{tabular}{|c|c|c|c|c|c|c|c|c|c|c|c|c|c|c|c|c|c|c|c|}
\hline \multirow{3}{*}{\multicolumn{2}{|c|}{ No. Halte }} & \multicolumn{15}{|c|}{ Paramater Eksisting Halte } & \multicolumn{3}{|c|}{ Parameter Pengguna } \\
\hline & & \multirow{3}{*}{$\begin{array}{l}\text { Tata Guna Lahan } \\
\text { Perbelanjaan }\end{array}$} & \multirow{2}{*}{\multicolumn{2}{|c|}{$\begin{array}{c}\text { Jarak Antar } \\
\text { Halte }\end{array}$}} & \multicolumn{3}{|c|}{ Jarak Halte Terhadap } & \multirow{2}{*}{\multicolumn{8}{|c|}{ Fasilitas Halte }} & \multirow{3}{*}{\begin{tabular}{|c}
$\begin{array}{c}\text { Dimensi } \\
\text { Halte }\end{array}$ \\
$\mathrm{x}$
\end{tabular}} & \multirow{4}{*}{$\begin{array}{c}\text { Jumlah } \\
\text { Menunggu } \\
\text { Angkutan }\end{array}$} & \multirow{4}{*}{$\begin{array}{c}\text { Jumlah } \\
\text { Pengguna } \\
\text { Halte }\end{array}$} & \multirow{4}{*}{$\begin{array}{c}\text { Kajian } \\
\text { Efektifitas }\end{array}$} \\
\hline & & & & & \multicolumn{2}{|c|}{ Fasilitas Pejalan Kaki } & \multirow{2}{*}{$\frac{\text { Persimpangan }}{\sqrt{ }}$} & & & & & & & & & & & & \\
\hline & 7 & & $\mathrm{x}$ & $\mathrm{x}$ & $\sqrt{ }$ & $\sqrt{ }$ & & $\mathrm{x}$ & $\mathrm{x}$ & $\mathrm{x}$ & $\mathrm{x}$ & $\sqrt{1}$ & $\mathrm{x}$ & $\mathrm{x}$ & $\sqrt{ }$ & & & & \\
\hline & 8 & Pertokoan & $\mathrm{x}$ & 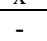 & $\mathrm{x}$ & $\sqrt{ }$ & $\mathrm{x}$ & $\mathrm{x}$ & $\mathrm{x}$ & $\mathrm{x}$ & $\mathrm{x}$ & $\sqrt{ }$ & $\mathrm{x}$ & $\mathrm{x}$ & $\sqrt{ }$ & $\mathrm{x}$ & & & \\
\hline \multirow{20}{*}{ 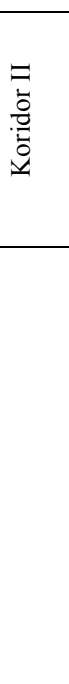 } & 1 & Pasar & - & $\sqrt{ }$ & $\sqrt{ }$ & $\mathrm{x}$ & $\sqrt{ }$ & $\sqrt{ }$ & $\sqrt{ }$ & $\sqrt{ }$ & $\mathrm{x}$ & $\sqrt{ }$ & $\mathrm{x}$ & $\sqrt{ }$ & $\mathrm{x}$ & $\sqrt{ }$ & \multirow{7}{*}{155 orang } & \multirow{7}{*}{53 orang } & \multirow{7}{*}{$\begin{array}{l}= \\
34,19 \% \\
\text { Tidak } \\
\text { Efektif }\end{array}$} \\
\hline & 2 & Pasar & $\sqrt{ }$ & $\sqrt{ }$ & $\sqrt{1}$ & $\mathrm{x}$ & $\sqrt{ }$ & $\sqrt{1}$ & $\sqrt{ }$ & $\sqrt{ }$ & $\mathrm{x}$ & $\sqrt{ }$ & $\mathrm{x}$ & $\sqrt{1}$ & $\mathrm{x}$ & $\sqrt{ }$ & & & \\
\hline & 4 & Perbelanjaan & $\sqrt{ }$ & $\mathrm{x}$ & $\sqrt{ }$ & $\mathrm{x}$ & $\sqrt{ }$ & $\mathrm{x}$ & $\mathrm{x}$ & $\mathrm{x}$ & $\mathrm{x}$ & $\sqrt{ }$ & $\mathrm{x}$ & $\mathrm{x}$ & $\mathrm{x}$ & $x$ & & & \\
\hline & 5 & Kantor & $\mathrm{x}$ & $\mathrm{x}$ & $\mathrm{x}$ & $\mathrm{x}$ & $\sqrt{ }$ & $\mathrm{x}$ & $x$ & $\mathrm{x}$ & $\mathrm{x}$ & $\sqrt{ }$ & $\mathrm{x}$ & $\mathrm{x}$ & $\mathrm{x}$ & $x$ & & & \\
\hline & 7 & Layanan Publik & $\sqrt{ }$ & $\sqrt{ }$ & $\sqrt{ }$ & $x$ & $\sqrt{ }$ & $\mathrm{x}$ & $\mathrm{x}$ & $\mathrm{x}$ & $\mathrm{x}$ & $\sqrt{1}$ & $\mathrm{x}$ & $\mathrm{x}$ & $\mathrm{x}$ & $x$ & & & \\
\hline & 8 & Sekolah & $\sqrt{ }$ & $\sqrt{ }$ & $\sqrt{ }$ & $\mathrm{x}$ & $\sqrt{ }$ & $\sqrt{ }$ & $\mathrm{x}$ & $\mathrm{x}$ & $\mathrm{x}$ & $\sqrt{ }$ & $\mathrm{x}$ & $\mathrm{x}$ & $\mathrm{x}$ & $\mathrm{x}$ & & & \\
\hline & 10 & Layanan Publik & $\sqrt{ }$ & $\mathrm{x}$ & $\sqrt{ }$ & $\mathrm{x}$ & $\sqrt{ }$ & $\sqrt{1}$ & $\mathrm{x}$ & $\mathrm{x}$ & $\mathrm{x}$ & $\sqrt{ }$ & $\mathrm{x}$ & $\mathrm{x}$ & $\mathrm{x}$ & $\mathrm{x}$ & & & \\
\hline & 11 & Pasar & $\mathrm{x}$ & $\sqrt{ }$ & $\sqrt{ }$ & $\mathrm{x}$ & $\mathrm{x}$ & $\mathrm{x}$ & $\mathrm{x}$ & $\mathrm{x}$ & $\mathrm{x}$ & $\sqrt{ }$ & $\mathrm{x}$ & $\mathrm{x}$ & $\mathrm{x}$ & $\mathrm{x}$ & & & \\
\hline & 13 & Perumahan & $\sqrt{ }$ & $\sqrt{ }$ & $\sqrt{ }$ & $x$ & $\sqrt{ }$ & $\sqrt{ }$ & $x$ & $\mathrm{x}$ & $\mathrm{x}$ & $\sqrt{ }$ & $\mathrm{x}$ & $\sqrt{ }$ & $\mathrm{x}$ & $\sqrt{ }$ & & & \\
\hline & 14 & Perumahan & $\sqrt{ }$ & $\sqrt{ }$ & $\sqrt{ }$ & $\mathrm{x}$ & $\sqrt{ }$ & $\mathrm{x}$ & $\mathrm{x}$ & $\mathrm{x}$ & $\mathrm{x}$ & $\sqrt{ }$ & $\mathrm{x}$ & $\mathrm{x}$ & $\mathrm{x}$ & $\mathrm{x}$ & & & \\
\hline & 16 & Sekolah & $\sqrt{ }$ & $\sqrt{ }$ & $\mathrm{x}$ & $\mathrm{x}$ & $\sqrt{ }$ & $\sqrt{ }$ & $\mathrm{x}$ & $\mathrm{x}$ & $\mathrm{x}$ & $\sqrt{ }$ & $\mathrm{x}$ & $\mathrm{x}$ & $\mathrm{x}$ & $\sqrt{ }$ & & & \\
\hline & 17 & Sekolah & $\sqrt{ }$ & $\mathrm{x}$ & $\mathrm{x}$ & $\mathrm{x}$ & $\sqrt{ }$ & $\sqrt{ }$ & $\mathrm{x}$ & $\mathrm{x}$ & $\mathrm{x}$ & $\sqrt{ }$ & $\sqrt{ }$ & $\mathrm{x}$ & $\sqrt{ }$ & $\mathrm{x}$ & & & \\
\hline & 19 & Perbelanjaan & $\mathrm{x}$ & $\sqrt{ }$ & $\mathrm{x}$ & $\mathrm{x}$ & $\sqrt{ }$ & $\mathrm{x}$ & $\mathrm{x}$ & $\mathrm{x}$ & $\mathrm{x}$ & $\sqrt{ }$ & $\mathrm{x}$ & $\mathrm{x}$ & $\sqrt{ }$ & $\mathrm{x}$ & & & \\
\hline & 20 & Perbelanjaan & $\sqrt{ }$ & $\mathrm{x}$ & $\sqrt{ }$ & $\mathrm{x}$ & $\sqrt{ }$ & $\mathrm{x}$ & $\mathrm{x}$ & $\mathrm{x}$ & $\mathrm{x}$ & $\sqrt{ }$ & $\mathrm{x}$ & $\mathrm{x}$ & $\sqrt{ }$ & $\mathrm{x}$ & & & \\
\hline & 22 & Sekolah & $\sqrt{ }$ & $\sqrt{ }$ & $\sqrt{ }$ & $\mathrm{x}$ & $\sqrt{ }$ & $\sqrt{ }$ & $\sqrt{ }$ & $\sqrt{ }$ & $\mathrm{x}$ & $\sqrt{ }$ & $\mathrm{x}$ & $\sqrt{ }$ & $\mathrm{x}$ & $\sqrt{ }$ & & & \\
\hline & 23 & Perbelanjaan & $\sqrt{ }$ & $\sqrt{ }$ & $\mathrm{x}$ & $\sqrt{ }$ & $\mathrm{x}$ & $\mathrm{x}$ & $\mathrm{x}$ & $\mathrm{x}$ & $\mathrm{x}$ & $\sqrt{ }$ & $\mathrm{x}$ & $\mathrm{x}$ & $\sqrt{ }$ & $\sqrt{ }$ & & & \\
\hline & 24 & Perbelanjaan & $\sqrt{ }$ & $\sqrt{ }$ & $\mathrm{x}$ & $\sqrt{ }$ & $\sqrt{ }$ & $\mathrm{x}$ & $\mathrm{x}$ & $\mathrm{x}$ & $\mathrm{x}$ & $\sqrt{ }$ & $\mathrm{x}$ & $\mathrm{x}$ & $\sqrt{ }$ & $\mathrm{x}$ & & & \\
\hline & 25 & Perbelanjaan & $\sqrt{ }$ & $\sqrt{ }$ & $\mathrm{x}$ & $\sqrt{ }$ & $\sqrt{ }$ & $\mathrm{x}$ & $\mathrm{x}$ & $\mathrm{x}$ & $\mathrm{x}$ & $\sqrt{1}$ & $\mathrm{x}$ & $\mathrm{x}$ & $\sqrt{ }$ & $\mathrm{x}$ & & & \\
\hline & 26 & Perbelanjaan & $\sqrt{ }$ & $\sqrt{ }$ & $\sqrt{ }$ & $\sqrt{ }$ & $\sqrt{ }$ & $\mathrm{x}$ & $\mathrm{x}$ & $\mathrm{x}$ & $\mathrm{x}$ & $\sqrt{ }$ & $\mathrm{x}$ & $\mathrm{x}$ & $\mathrm{x}$ & $\mathrm{x}$ & & & \\
\hline & 28 & Layanan Publik & $\sqrt{ }$ & - & $\sqrt{ }$ & $\sqrt{ }$ & $\sqrt{ }$ & $\mathrm{x}$ & $\mathrm{x}$ & $\mathrm{x}$ & $\mathrm{x}$ & $\sqrt{ }$ & $\mathrm{x}$ & $\mathrm{x}$ & $\mathrm{x}$ & $\mathrm{x}$ & & & \\
\hline \multirow{5}{*}{ 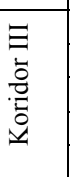 } & 1 & Layanan Publik & - & $\mathrm{x}$ & $\sqrt{ }$ & $\sqrt{ }$ & $\sqrt{ }$ & $\mathrm{x}$ & $\mathrm{x}$ & $\mathrm{x}$ & $\mathrm{x}$ & $\sqrt{ }$ & $\mathrm{x}$ & $\mathrm{x}$ & $\mathrm{x}$ & $\mathrm{x}$ & \multirow{5}{*}{$\begin{array}{c}39 \\
\text { Responden }\end{array}$} & \multirow{5}{*}{$\begin{array}{c}12 \\
\text { Responden }\end{array}$} & \multirow{5}{*}{$\begin{array}{l}= \\
30,77 \% \\
\text { Tidak } \\
\text { Efektif }\end{array}$} \\
\hline & 2 & Pasar & $\mathrm{x}$ & $\mathrm{x}$ & $\sqrt{ }$ & $\mathrm{x}$ & $\sqrt{ }$ & $\mathrm{x}$ & $\mathrm{x}$ & $\mathrm{x}$ & $\mathrm{x}$ & $\sqrt{ }$ & $\mathrm{x}$ & $\mathrm{x}$ & $\mathrm{x}$ & $\mathrm{x}$ & & & \\
\hline & 4 & Sekolah & $\sqrt{ }$ & $\mathrm{x}$ & $\sqrt{ }$ & $\mathrm{x}$ & $\sqrt{ }$ & $\mathrm{x}$ & $\mathrm{x}$ & $\mathrm{x}$ & $\mathrm{x}$ & $\sqrt{ }$ & $\mathrm{x}$ & $\mathrm{x}$ & $\mathrm{x}$ & $\sqrt{ }$ & & & \\
\hline & 5 & Pemukiman & $\mathrm{x}$ & $\mathrm{x}$ & $\sqrt{ }$ & $\sqrt{ }$ & $\mathrm{x}$ & $\mathrm{x}$ & $x$ & $\mathrm{x}$ & $\mathrm{x}$ & $\sqrt{ }$ & $\mathrm{x}$ & $\mathrm{x}$ & $\mathrm{x}$ & $\mathrm{x}$ & & & \\
\hline & 7 & Layanan Publik & $\mathrm{x}$ & - & $\mathrm{x}$ & $\sqrt{ }$ & $\sqrt{ }$ & $\mathrm{x}$ & $\mathrm{x}$ & $\mathrm{x}$ & $\mathrm{x}$ & $\sqrt{ }$ & $\mathrm{x}$ & $\mathrm{x}$ & $\mathrm{x}$ & $\mathrm{x}$ & & & \\
\hline \multirow{4}{*}{$\stackrel{\overrightarrow{0}}{\overrightarrow{0}} \geq$} & 1 & Sekolah & - & $\mathrm{x}$ & $\mathrm{x}$ & $\mathrm{x}$ & $\sqrt{ }$ & $\mathrm{x}$ & $\mathrm{x}$ & $\mathrm{x}$ & $\mathrm{x}$ & $\sqrt{ }$ & $\mathrm{x}$ & $\mathrm{x}$ & $\mathrm{x}$ & $\mathrm{x}$ & 31 & 11 & $=$ \\
\hline & 3 & Kantor & $\mathrm{x}$ & $\mathrm{x}$ & $\sqrt{ }$ & $\mathrm{x}$ & $\sqrt{ }$ & $\mathrm{x}$ & $\mathrm{x}$ & $\mathrm{x}$ & $\mathrm{x}$ & $\mathrm{x}$ & $\mathrm{x}$ & $\mathrm{x}$ & $\mathrm{x}$ & $\mathrm{x}$ & Responden & Responden & $33,46 \%$ \\
\hline & 4 & Sekolah & $\mathrm{x}$ & $\mathrm{x}$ & $\mathrm{x}$ & $\mathrm{x}$ & $\sqrt{ }$ & $\mathrm{x}$ & $\mathrm{x}$ & $\mathrm{x}$ & $\mathrm{x}$ & $\sqrt{ }$ & $\mathrm{x}$ & $\mathrm{x}$ & $\mathrm{x}$ & $\mathrm{x}$ & & & Tidak \\
\hline & 5 & Hotel & $\mathrm{x}$ & - & $\mathrm{x}$ & $\mathrm{x}$ & $\mathrm{x}$ & $\mathrm{x}$ & $\mathrm{x}$ & $\mathrm{x}$ & $\mathrm{x}$ & $\sqrt{ }$ & $\mathrm{x}$ & $\mathrm{x}$ & $\sqrt{ }$ & $\mathrm{x}$ & & & Efektif \\
\hline
\end{tabular}

Berdasarkan tabel di atas diketahui nilai efektifitas penggunaan halte pada masing-masing koridor. Nilai efektifitas pada masing-masing koridor berada diantara 20,10\%-40,00\% dengan kriteria tidak efektif. Untuk nilai efektifitas penggunaan halte di Kota Medan dapat diketahui sebagai berikut:

Efektifitas Penggunaan Halte Kota Medan $=(31,91 \%+34,19 \%+30,77 \%+33,46 \%) / 4=32,58 \%$

Nilai efektifitas penggunaan halte di Kota Medan adalah 32,58\% dimana nilai ini terletak diantara 20,10\%-40,00\% dengan kriteria tidak efektif. Berdasarkan kriteria tersebut maka dapat disimpulkan bahwa penggunaan halte di Kota Medan adalah tidak efektif. 


\section{Rancangan Desain dan Optimalisasi Penggunaan Halte}

Para calon penumpang yang menunggu angkutan umumnya cenderung berada pada kawasan kegiatan sekolah, pasar, pusat perbelanjaan, perkantoran, pemukiman, hotel/penginapan dan tempat ibadah. Penumpang tersebut cenderung menunggu angkutan di persimpangan jalan dan bukan pada halte yang tersedia. Pusat-pusat kegiatan dan persimpangan jalan sering menjadi lokasi tiban (tempat ngetem angkutan umum). Hal ini terjadi karena letak halte terlalu jauh dari persimpangan jalan maupun dari pusat kegiatan, maka keberadaan halte dan letak halte perlu dipertimbangkan dan disesuaikan dengan kondisi ruas jalan maupun pusat kegiatan tersebut. Adapun tata letak halte terhadap ruang lalu lintas agar disesuaikan berdasarkan keputusan Direktorat Jenderal Perhubungan Darat.

Adapun pedoman praktis dalam menentukan lokasi halte yang efektif dan efesien harus memenuhi syarat sebagai berikut:

1. Halte terletak pada trotoar dengan ukuran sesuai dengan kebutuhan.

2. Halte diletakkan di muka pusat kegiatan yang banyak membangkitkan pemakai angkutan umum.

3. Halte diletakkan di tempat yang terbuka dan tidak tersembunyi.

Jarak jangkauan calon pengguna angkutan umum terhadap halte terdekat yang diperoleh dari hasil penelitian adalah 200-400 m. Jarak ini akan dirasakan para pengguna angkutan umum sebagai jarak berjalan kaki yang cukup melelahkan dan berkeringat, mengingat kondisi cuaca dan iklim Kota Medan yang terik terutama pada siang hari sehingga pengguna tidak rela berjalan kaki pada jarak tersebut, dengan demikian penempatan halte di depan pusat kegiatan sangat perlu dipertimbangkan demi optimalnya fungsi halte tersebut. Perletakan halte pada persimpangan jalan yang dianjurkan untuk meningkatkan dan mengoptimalkan penggunaan halte di Kota Medan dapat dilihat pada Gambar 6 dan Gambar 7 berikut :

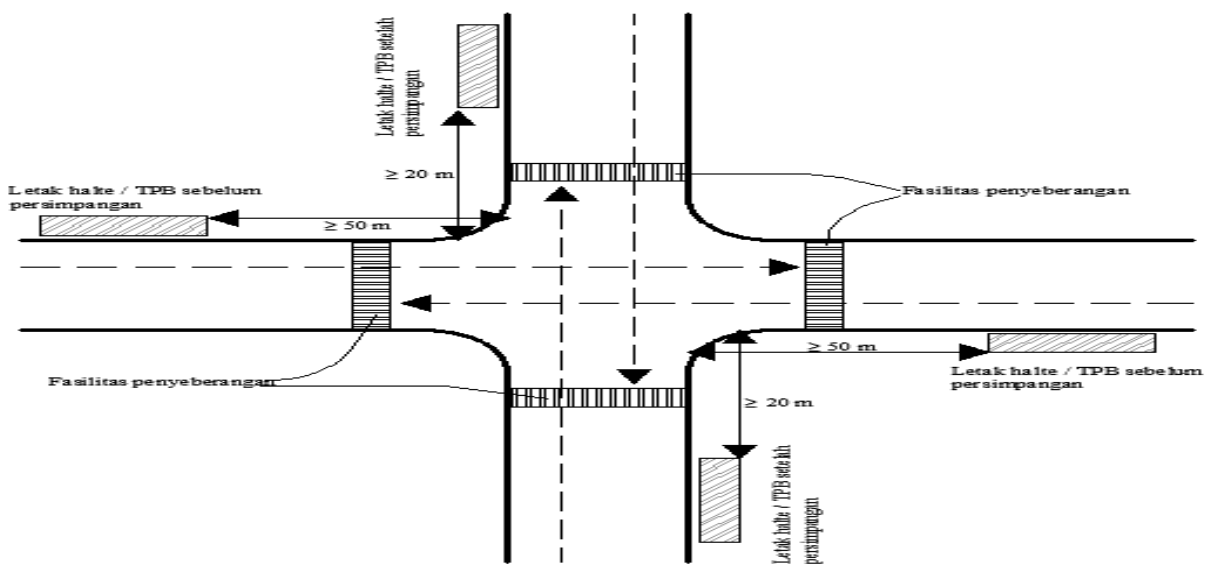

Gambar 6 Perletakan Halte di Pertemuan Jalan Simpang Empat

Optimalnya penggunaan halte akan menjadi maksimal jika jumlah halte pada ruas-ruas jalan di Kota Medan memiliki jarak antar halte 200-400 m. Sehingga, penambahan jumlah halte pada ruas-ruas jalan di Kota Medan sangat diperlukan. Untuk halte yang saling berdekatan, dalam peneletian ini diperoleh beberapa halte yang memiliki jarak terhadap halte berikutnya $\leq 10 \mathrm{~m}$ untuk mentiadakan salah satu dari halte tersebut yang tidak layak digunakan. 


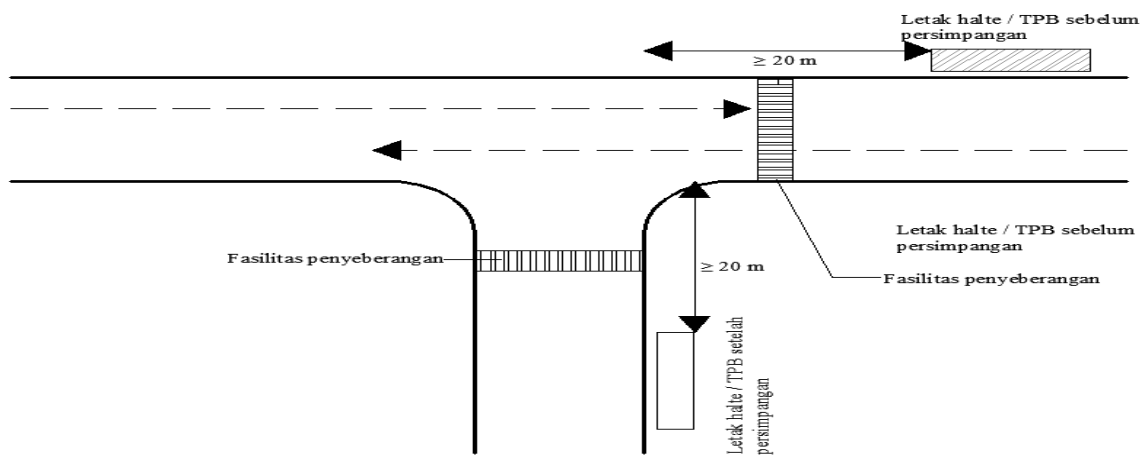

Gambar 7 Perletakan Halte di Pertemuan Jalan Simpang Tiga

Optimalisasi halte di Kota Medan juga dapat dengan melengkapai fasilitas-fasilitas utama dan tambahan pada halte seperti identitas halte, rambu petunjuk, papan informasi trayek, lampu penerangan, tempat duduk, telepon umum, tempat sampah, pagar pembatas, dan papan iklan. Selain hal tersebut dimensi halte juga sangat mempengaruhi keefektifan suatu halte. Dimensi halte yang digunakan harus memiliki panjang $\geq 4 \mathrm{~m}$ dan lebar $\geq 2 \mathrm{~m}$. Dimensi dan rancang bangun halte dapat dilihat pada Gambar 7 dan Gambar 8 berikut ini.

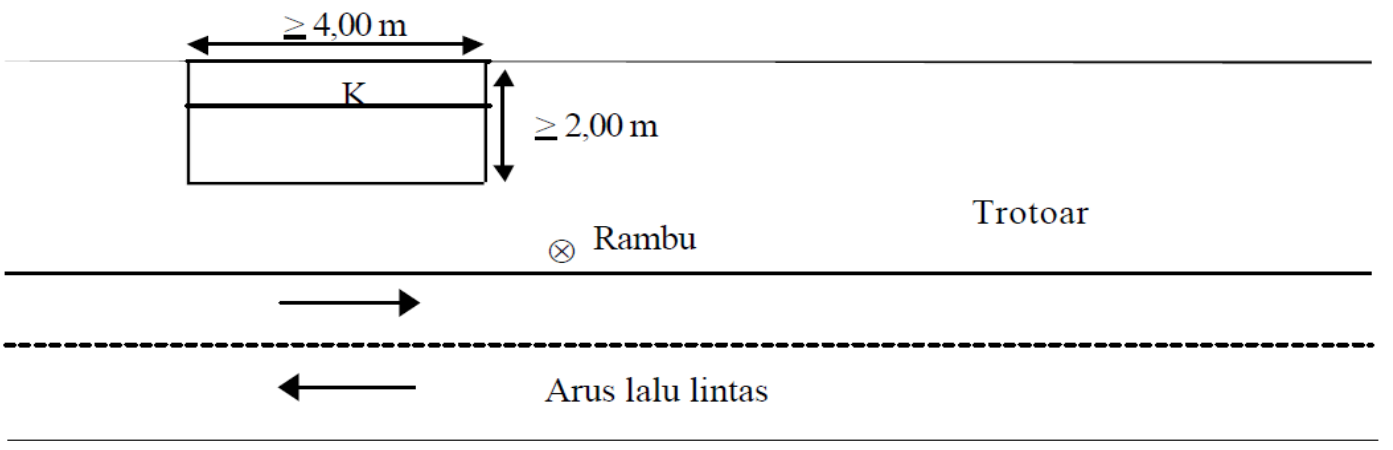

$\mathrm{K}=$ tempat duduk

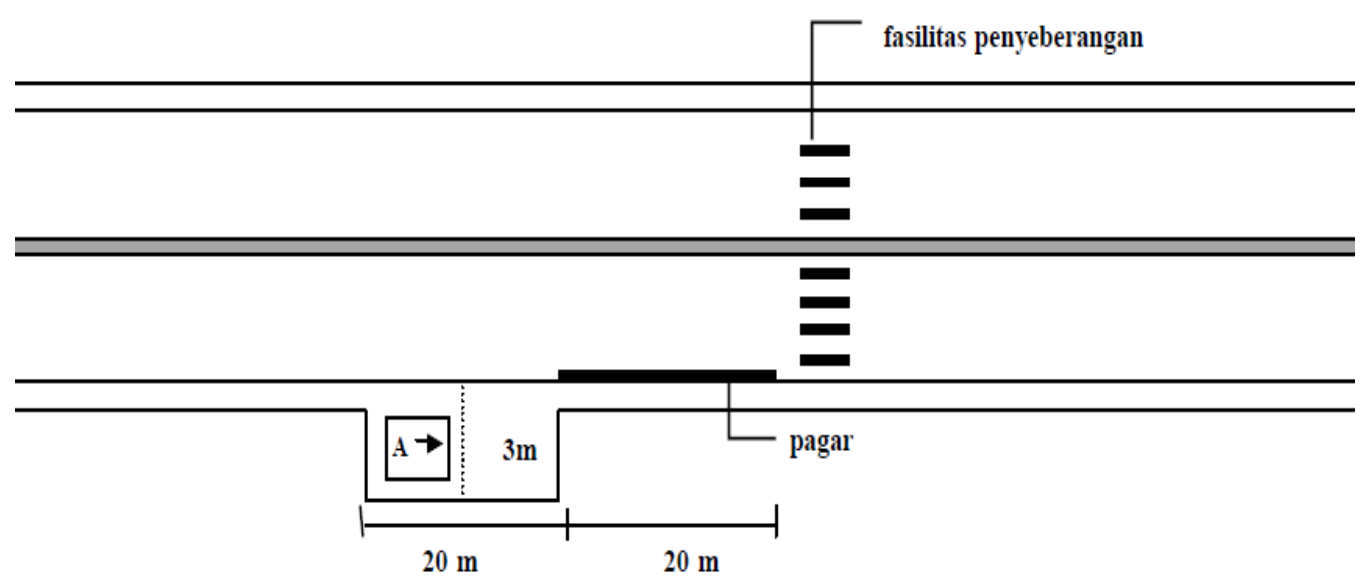

Gambar 8 Dimensi Panjang, Lebar dan Jarak Halte Terhadap Fasilitas Penyeberang Pejalan Kaki 

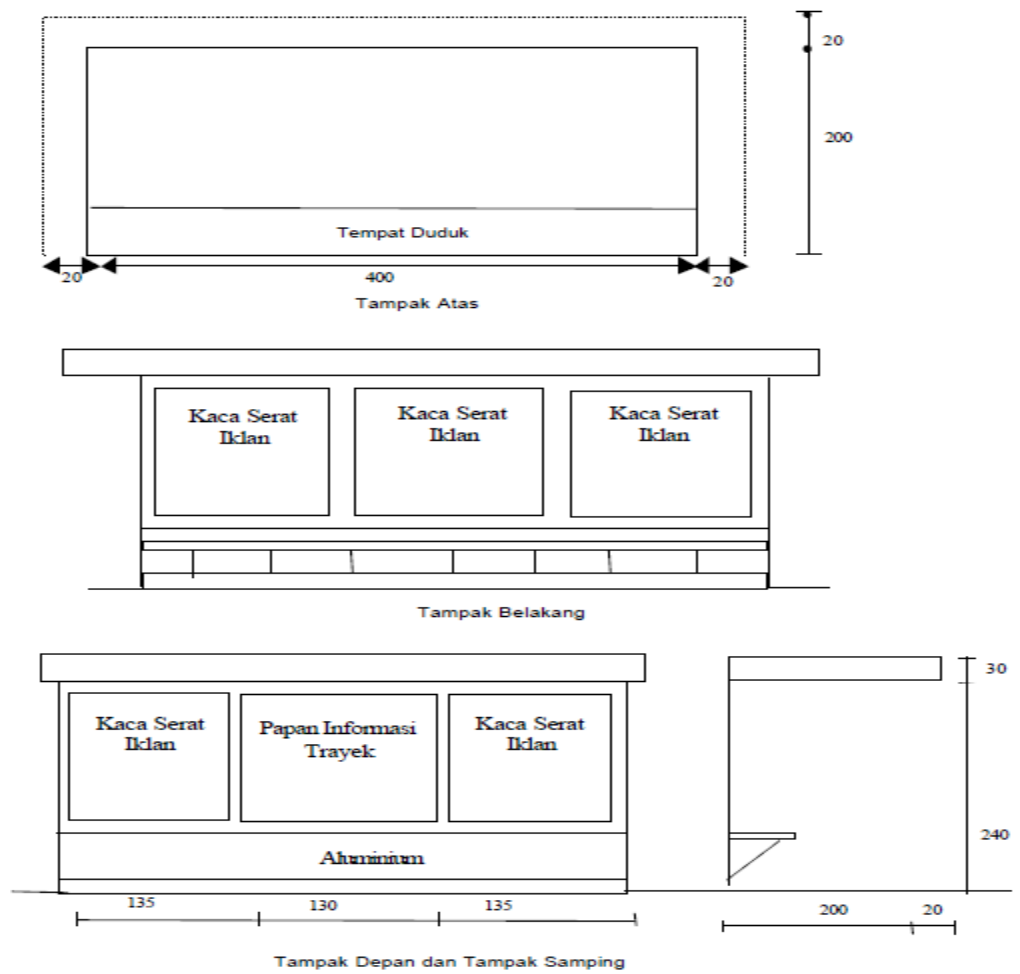

Gambar 8 Rancang Bangun Halte

Halte dirancang dapat menampung penumpang angkutan umum 20 orang per halte pada kondisi biasa (penumpang dapat menunggu dengan nyaman). Pada Gambar 9 dijelaskan dimensi dan kapasitas lindungan halte sebagai berikut.

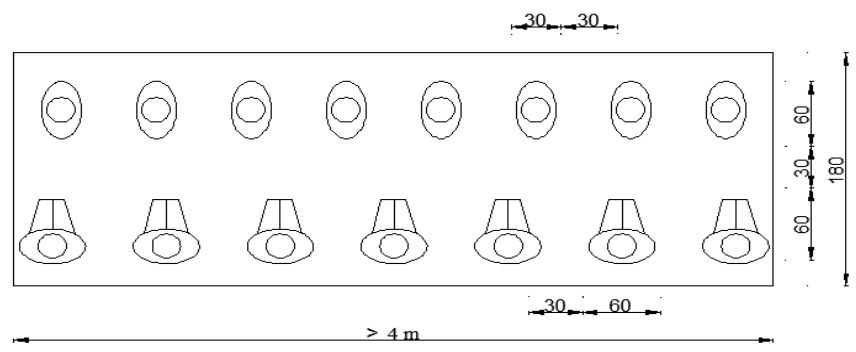

Gambar 9. Kapasitas Halte

Keterangan gambar:

a. Ruang gerak penumpang di tempat henti $90 \mathrm{~cm} \times 60 \mathrm{~cm}$

b. Jarak bebas antar penumpang dalam kota $30 \mathrm{~cm}$ dan antar kota $60 \mathrm{~cm}$

c. Ukuran tempat henti perkendaraan, panjang $12 \mathrm{~m}$ dan lebar $2,5 \mathrm{~m}$

d. Ukuran halte minimum $4,00 \mathrm{~m} \times 2,00 \mathrm{~m}$

Dalam meningkatkan keefektifan penggunaan halte di Kota Medan maka kebijaksanaan operasional angkutan kota yang berkaitan dengan perhentian sangat diperlukan yaitu: Flag Stop, Set-Stop dan Mixed Stop. Selain kebijakan di atas untuk meningkatkan keefektifan penggunaan halte di Kota Medan sanksi yang tegas juga diperlukan bagi pengemudi dan calon penumpang angkutan umum yang menaikkan dan menurunkan penumpang atau memberhentikan angkutan umum di sembarangan tempat dan bukan pada halte atau tempat yang ditentukan. 


\section{Kesimpulan}

a. Sebanyak 16 halte $(45,71 \%)$ dengan tipe mid-block (letak halte cukup jauh dari persimpangan), 8 halte $(22,86 \%)$ dengan tipe far-side halte terletak setelah persimpangan) dan 11 halte $(31,43 \%)$ dengan tipe near-side (halte terletak sebelum persimpangan). Dari keseluruhan halte yang diteliti hanya 9 halte $(25,71 \%)$ memiliki dimensi yang sesuai standar halte, 8 halte $(22,86 \%)$ yang memiliki identitas nama. Ditinjau dari kelengkapan fasilitas diketahui 3 halte $(8,57 \%)$ yang memiliki info papan trayek, 1 halte $(2,86 \%)$ memiliki lampu penerangan, 33 halte $(94,26 \%)$ memilik tempat duduk, 2 halte $(5,71 \%)$ memiliki tempat sampah, 5 halte $(14,26 \%)$ memiliki pagar pembatas dan 9 halte $(25,71 \%)$ memiliki papan iklan.

b. Faktor-faktor yang mempengaruhi penggunaan halte adalah pengetahuan tentang halte, jarak jangkauan ke halte, waktu tunggu angkutan di halte, penempatan halte dan fasilitas halte, tata guna lahan, fasilitas pejalan kaki dan kemudahan memproleh angkutan umum.

c. Karakteristik penggunaan halte pada Kota Medan adalah halte yang terletak pada tataguna lahan layanan publik, sekolah, pasar, pertokoan dan kantor yang dilengkapi dengan fasilitas halte maupun fasilitas pejalan kaki berupa zebra cross dan jembatan penyeberangan orang (JPO).

d. Sebanyak 33,46\% responden cenderung menggunakan halte dalam menunggu angkutan umum dan wanita merupakan yang terbanyak menggunakan halte $(23,89 \%)$. Respon cenderung berusia $16-20$ tahun $(13,60 \%)$ dengan tingkat pendidikan responden penggunana halte adalah SMA (18,75\%), sehingga pengguna halte merupakan pelajar dan mahasiswa $(29,04 \%)$.

e. Nilai efektifitas penggunaan halte di Kota Medan adalah 32,58\% dengan kriteria keefektifan adalah tidak efektif.

\section{Daftar Pustaka}

Basuki, K.H. (2006). Fungsi Halte Sebagai Tempat Henti Angkutan Umum. Semarang BPS Kota Medan. (2016). Medan Dalam Angka. Medan: Badan Pusat Statistik Kota Medan

Catur, R., Hardjanta, G., \& Hindarto, F. (2001). Faktor-Faktor Yang Mengakomodasikan Ketidakefektifan Penggunaan Halte.

Daud, J. (2005). Studi Efektifitas Penggunaan Halte di Kota Medan. Jurnal Sistem Teknik Industri, (3). Hal 73-78

Direktorat Jendral Bina Marga. (1990). Petunjuk Tertib Pemanfaatan Jalan. Jakarta: Pekerjaan Umum

Direktorat Jendral Perhubungan Darat. (1996). Pedoman Teknis Perekayasaan Tempat Perhentian Kendaraan Penumpang Umum. Keputusan Direktur Jendral Perhubungan Darat (Nomor: 271/HK.105/DRJD/96)

Dinas Kependudukan dan Catatan Sipil. (2016). Kependudukan Kota Medan 2011-2015.

Morlok, E. K. (1978). Introduction to transportation engineering and planning. McGraw-Hill College.

Peraturan Pemerintah Republik Indonesia Nomor 43 Tahun 1993 Tentang Prasarana Dan Lalu Lintas Jalan, 14 Juli 1993

Peraturan Pemerintah Republik Indonesia No. 41 Pasal 8 Tahun 1993. Tentang Angkutan Jalan

Rencana Tata Ruang Wilayah Kota Medan Tahun 2016-2030. BAPPEDA Medan

Isaac, S., \& Michael, W. B. (1981). Handbook in research and evaluation: For education and the behavioral sciences. San Diego, CA: EdITS.

Sudjana. (2005). Metoda Statistika. Bandung: PT. Tarsito

Sugiyono. (2010). Metode Penelitian Kuantitatif Kualitatif dan R\&D. Bandung: Alfabeta

Vuchic, VR. (1981). Urban Public Transportation System and Technology. New Jersey: Prentice-all, Inc. 